\title{
EL PECADO DE SER HOMBRES
}

\section{Algunas consideraciones acerca del relato de la "caída original"}

Uno de los pasajes de la Escritura veterotestamentaria que más ha marcado la teología cristiana es sin duda el relato de Gn 3. El texto ha sido interpretado a lo largo de la historia como una etiología del mal en el hombre: en él se describe el origen del pecado, cometido en los albores de la humanidad y heredado por ella como lastre inapelable. De él se explican todos los males que surcan la dramática historia humana. De él ha seguido la condena de la muerte.

\begin{abstract}
"Se ve claramente que lo que el relato bíblico ha querido enseñar es que, frente a la creación que ha nacido buena de las manos de Dios, el mal, el pecado, el sufrimiento y la muerte se deben al mal uso de la libertad que el hombre hizo al inicio de la historia. Esto es lo esencial del relato de $\mathrm{Gn} 3$ y que no pertenece, por tanto, al material mítico, sino que, procediendo de una reflexión propia del autor, constituye la revelación fundamental que Dios hace en esas páginas. El fin que se propone el autor es explicar el trastorno que produjo el pecado de Adán invirtiendo las relaciones entre Dios y el hombre." ${ }^{1}$
\end{abstract}

Sobre este presupuesto descansa en gran medida toda la cristología, como bien lo pone de manifiesto la creatividad retórica del felix culpa. De allí que siga una consecuencia: "el cristiano sabe que no

${ }^{1}$ J. A. SAYÉs, Teología de la creación, Madrid, 2002, p. 386. 
se puede menospreciar la hondura del pecado original sin atentar contra el misterio de Cristo." 2

Para esta interpretación hecha tradicional han jugado un rol fundamental un modo literal de interpretar la Escritura y la transposición de la trama intradiegética al plano de una etiología a nivel histórico. Ello ha generado una comprensión que ha pasado a formar parte del patrimonio teológico-doctrinal. ${ }^{3}$ Si bien hoy se es más atento a distinguir lo simbólico y el género literario del relato y se evita interpretarlo como un protocolo exacto de lo sucedido, subsisten aún formas insuficientes de interpretar el texto. Se ha dicho con razón que quizás no exista otro texto bíblico que haya sido tan malinterpretado como Gn $3 .^{4}$ El estilo mítico del relato no permite extraer noticias o contenidos históricos sobre un supuesto primer hombre o primera pareja. Tampoco sobre un estado paradisíaco inicial, previo a la "caída".

No pretendo aquí entrar de lleno en la compleja temática del "pecado original" ni en las consecuencias que se han extraído desde una determinada manera de comprenderlo, si bien ello sería una cuestión necesaria. El propósito de esta contribución es menos ambicioso. Sin aspirar a discutir todos los pormenores del texto ni a tener en cuenta la frondosa bibliografía existente, intento ofrecer en primer lugar una interpretación en la cual la pointe del texto no está dada fundamentalmente por la etiología del pecado sino ante todo por una cuestión antropológica: ¿qué es el hombre? ¿cómo es posible que el ser humano sea conocedor del bien y del mal y, a la vez, mortal? Esta

2 J. A. SAYÉs, Teología, p. 379. Constata críticamente I. P. G. Gous, «Snakes and ladders. Mind Games in Genesis 2 and 3», en: Journal for Semitics 19/1 (2010), pp. 113-127, 117: "Church doctrine seems to be only interested in wanting this passage to be historically true in order to substantiate original sin, in order that the death, resurrection and redemption by Jesus Christ becomes a necessity." Cf. también Z. ZEVIT, What really happened in the Garden of Eden?, New Haven London, 2013, p. xxiv.

3 En sentido estricto, la doctrina del pecado original expuesta en el Concilio de Trento no se apoya en el relato de Gn 3 en sí, sino en Rm 5,12, es decir, en la lectura paulina del texto e inspirada en la interpretación agustiniana de éste. La presente contribución intenta analizar fundamentalmente el sentido del relato.

4 Cf. W. BruegGemann, Genesis. A Bible commentary for teaching and preaching. Atlanta, 1982, p. 41, citado en I. Gous, «Snakes and ladders», p. 114. 933.

5 Cf. T. PrÖPPER, Theologische Anthropologie, Bd. 2, Freiburg i. Br. 2011, p. 
condición, ¿es una pretensión soberbia, buscada a través de una usurpación inmoral o pertenece a su constitución? Formulado también en forma de preguntas: el diálogo entre la serpiente y la mujer, ¿es de seducción o de revelación? La afirmación de la serpiente "Serán como dioses", ¿es una tentación o una constatación? (1). En una segunda parte del artículo ofrezco un análisis de las respectivas sentencias de Dios a la serpiente, a la mujer y a Adán. El punto más importante de esta parte es el tema de la muerte: ¿ella es entendida como sanción por la usurpación cometida o el relato sobreentiende un hombre creado mortal desde el inicio? Algunas observaciones sobre la recepción del texto siguen a esta discusión (2). La tercera y última parte se propone ofrecer algunas consideraciones sintéticas sobre algunas cuestiones que considero importantes y que ameritarían un replanteo amplio (3).

\section{Un diálogo revelador}

Tras el relato no sacerdotal de la creación y la afirmación de la unidad del varón y de la mujer (Gn 2,4b-25), ${ }^{6}$ el narrador introduce a la serpiente, el animal del campo más astuto de entre los creados: הָָָּּ (Gn $2,24)$. No ha sido mencionado previamente de manera especial en la narración de la creación (cf. Gn 2,19), de modo que su irrupción en la escena bíblica es improvisa e inesperada. El hecho de iniciar la frase con el sujeto y no con el verbo marca una ruptura con la secuencia anterior. ${ }^{7}$

La serpiente es inmediatamente caracterizada como עָר que no se encuentra sino un puñado de veces en textos sapienciales ( $\mathrm{Pr}$

6 El texto era anteriormente considerado como obra del "Yahvista" y datado en la "época salomónica", según la entonces vigente teoría documentaria. Hoy la crítica exegética distingue entre textos sacerdotales y no sacerdotales. Según opinión perita, el texto se ubica en época tardía: exílica o postexílica. Un indicio importante de ello es que el relato parece no haber sido conocido por los textos más antiguos de la Escritura y sólo se hace referencia a él en textos claramente tardíos. Cf. F. GARCIA LÓPEZ, «Los fundamentos de la antropología bíblica. Gn 1-3 a la luz de los estudios exegéticos recientes», en Salmanticensis 58 (2001), pp. 191204, 192-193; J.-L. SKA, II cantiere del Pentateuco. V. 1. Problemi di composizione e di interpretazione, Bologna, 2013, pp. 54-63; A. SCHÜLE, «Made in the >Image of God<: The Concepts of Divine Images in Gen 1-3», en ZAW 117/1 (2005), pp. 1-20, 3 n. 7.

7 Cf. Z. ZEVIT, Garden of Eden, pp. 161-162. 
$12,16.23 ; 13,16 ; 14,8.15 .18 ; 22,3 ; 27,12)$ y no está marcado necesariamente por un significado negativo, ${ }^{8}$ si bien este matiz puede aparecer ocasionalmente en algunos textos (cf. Jb 5,12; 15,5). ${ }^{9}$ Ello es un elemento que se suma a los motivos sapienciales que coloran el relato (la creación a partir del polvo, el árbol de la vida, el jardín de Dios y el jardín de Edén). ${ }^{10}$ Tampoco la serpiente es tachada de perversa; más aún: "En ningún lugar de la Biblia hebrea se hace referencia a la serpiente como una creatura rāšac, malvada o mala.",

A nivel intradiegético, se trata siempre de una serpiente y en ella no hay ninguna alusión al diablo. No hay aquí ningún fundamento para

8 Cf. Z. ZEVIT, Garden of Eden, p. 163: "The serpent was cārûwm. People characterized as cârûwm conceal what they feel and what they know (Prov 12:16, 23). They esteem knowledge and plan how to use it in achieving their objectives (Prov 13:16; 14:8, 18); they do not believe everything that they hear (Prov 14:15); and they know how to avoid trouble and punishment (Prov 22:3; 27:12). Im sum, they are shrewd and calculating, willing to bend and torture the limits of acceptable behavior but not to cross the line into illegalities. They may be unpleasant and purposely misleading in speech but are not out-and-out liars Josh 9:4 1; 1 Sam 23:22). They know how to read people and situations and how to turn their readings to advantage. A keen wit and a rapier tongue are their tools".

9 Cf. F. Giuntol (a cura di), Genesi 1-11. Introduzione, traduzione e commento, Milano, Cinisello Balsamo, 2013, p. 99.

10 Cf. J.-L. SKA, I/ cantiere, pp. 54-57. Una presentación más detenida de los textos puede verse en M. WITTE, «Die biblische Urgeschichte. Redaktions- und theologiegeschichtliche Beobachtungen zu Genesis 1,1-11,26» (BZAW 265), Berlin - New York, 1998, pp. 200-205. Sobre el motivo del jardín, según algunos, se pueden distinguir tres tipos: los pertenecientes al mundo real y que expresan su poder; los cultuales y los pertenecientes a los relatos míticos, como en el poema de Gilgamés. Éstos últimos constituyen, según algunos, el trasfondo probable del relato del Génesis. Cf. T. STORDALEN, Echoes of Eden. Genesis 2-3 and Symbolism of the Eden Garden in Biblical Hebrew Literature (Contributions to Biblical Exegesis and Theology 25) Leuven, 2000, pp. 94-104; 111-116. Para otros, en cambio, el paralelo más cercano está dado por el motivo del jardín real. Cf. A. VAN DER KOOIJ, «The story of Paradise in the light Mesopotamian culture and literature», en K. J. Dell / G. Davies / Y. Von KOH (eds.), Genesis, Isaiah and Psam/s. A Festschrift to honour Professor John Emerton for his eightieth birthday, Leiden - Boston, 2010, pp. 8-9. Si bien este último autor parece buscar una correspondencia entre cada detalle de los relatos, en lugar de entender un trasfondo común, adaptado libre y creativamente - sin correspondencias exactas - por cada relato en particular, es interesante la descripción de los jardines reales que cita. A su juicio, en este contexto, es "natural" leer en Gn 3,8 que Dios se "pasea por el jardín". Cf. A. FuCHS, Die Inschriften Sargons II. aus Khorsabad, Göttingen, 1994, p. 309.

11 Z. ZEVIT, Garden of Eden, p. 163. 
considerar que se trate del "demonio, autor del pecado". 12 Esta interpretación se encuentra recién en el tardío libro de la Sabiduría:

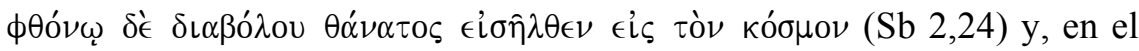
Nuevo Testamento, en el último libro del canon, cuando se lo designa

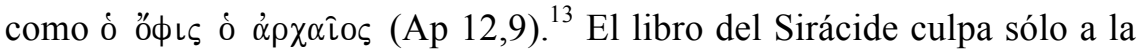

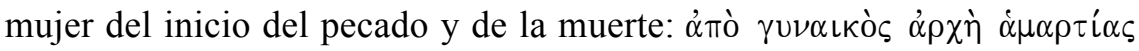

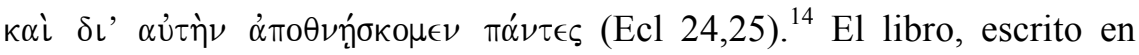
torno al 180 a.C. es el testimonio más antiguo de la interpretación contra Eva. ${ }^{15}$ Sobre todo es interesante notar que ni siquiera Pablo realiza esta vinculación: en el paralelismo que realiza con Cristo, el pecado se atribuye exclusivamente a Adán (cf. Rm 5,12-19) y cuando alude a la serpiente y a Eva no hay ninguna relación explícita de aquella con el diablo (cf. 2 Co 11,3). Tampoco lo hace explícitamente el autor de la primera carta a Timoteo (cf. 1 Tm 2,13-14). Fuera del canon bíblico, la

12 Conferencia Episcopal Argentina, Ritual Romano de los Sacramentos. Sacramento del bautismo, Buenos Aires, 1999, n. 54.

13 La afirmación de Z. ZEVIT, Garden of Eden, p. 163 según la cual “(o)nly in medieval interpretation was the devious fused with the evil, creating a devil. Thus a serpent in the Garden was transformed into Satan who rules in Hell" es, por tanto, imprecisa. La "metamorfosis" de la serpiente en diablo ya está atestiguada previamente. La afirmación joanéa en la que se dice del diablo que ékễvos

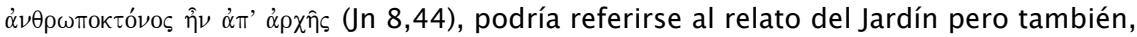
según otros, podría ser una alusión al relato de Caín y de Abel. Cf. J. ZUMSTEIN, L'Évangile selon Saint Jean (1-12), (CNT IVa, deuxième série), Genève, 2014, p. 302 y n. 109. El texto de $1 \mathrm{Jn}$ 3,12-15 sugiere más bien esta última posibilidad. Cf. H. THYEN, Das Johannesevangelium (HNT 6), Tübingen, 2005, p. 446. Son los únicos dos textos en los que aparece la palabra $\alpha \nu \theta \rho \omega \pi$ mótónos. Es crítico de esta interpretación M. THEOBALD, Das Evangelium nach Johannes. Kapitel 1-12 (RNT), Regensburg 2009, p. 605. L. H. RIVAS, El evangelio de Juan. Introducción. Teología. Comentario, Buenos Aires, 2005, pp. 277-281 explica la cuestión como una alusión al texto del Génesis leído a la luz de la tradición judía según la cual Caín era hijo del diablo. Para ello ofrece abundante documentación de la literatura apócrifa y rabínica. La afirmación de Rm 16,20 no parece, a mi juicio, una alusión directa al relato del Génesis.

14 Cf. también Sir 17,1-10 donde está ausente toda mención del pecado y el autor parece entender la muerte como el límite natural establecido por Dios.

15 Cf. Z. ZeVIT, Garden of Eden, p. 10. También, sobre la historia de la interpretación de la mujer como responsable del pecado y de la muerte en el mundo, cf. H. SCHÜNGEL-STRAUMENN, «Frau am Anfang. Eva und die Folgen (EXUZ 6)», Münster, 21997, pp. 25-56, citado en A. SCHÜLE, Der Prolog der hebräischen Bibel. Der literar- und theologiegeschichtliche Diskurs der Urgeschichte (Genesis 1-11) (AThANT 86), Zürich, 2006, p. 156. 
vinculación de la serpiente con el diablo está atestiguada en textos tardíos. $^{16}$

En la narración del Génesis, la serpiente es una de las creaturas terrestres que Dios acaba de crear y a la cual el varón ha dado un nombre (cf. Gn 2,20). ${ }^{17}$ Ella es la única que toma la palabra en el relato. En la biblia hebrea hay algunos ejemplos de textos en los cuales seres inanimados hablan como seres humanos (cf. p.e. Nm 22,22-35; Jue 9,8$15 ; 2 \mathrm{R} 14,9$ ). Éste es un elemento propio de las fábulas, si bien el relato, a juicio de J.-L. Ska, no se puede incluir en este género. ${ }^{18}$ El castigo que le viene infligido por haber inducido a la mujer a desobedecer el mandamiento divino, como se verá, confirma esta observación: es maldita entre todos animales del campo, deberá arrastrarse sobre su vientre, comiendo polvo y padecerá una constante enemistad con el linaje humano. Imposible considerar que alguna de estas consecuencias pudiese ser un castigo adecuado para el diablo. En este sentido, no encuentra ningún apoyo cierto la afirmación de Sayés, según la cual "se deduce por el contexto" que sea el demonio. ${ }^{19}$ La deducción es gratuita.

Cuando la serpiente toma la palabra, lo hace remitiendo al mandato dado por Dios al varón, cuando aún no había sido creada la mujer (cf. Gn 2,16b-17). Allí Dios establece que el varón puede comer de todo árbol

16 Así por ejemplo los Targumin Neophyti I y Pseudo-Johanatan a Gen 3,15. Cf. F. GIUnTOLI, Genesi, p. 105.

17 También aparece una serpiente en la epopeya de Gilgamés. Cf. Z. ZEVIT, Garden of Eden, pp. 165-166; F. GIUNTOLi, Genesi, p. 100; E. NARDONI, «Género literario y teología de Génesis 2-3», en Revista Bíblica Argentina 70 (1998/2), pp. 65-90, 72. Según éste último, la serpiente del Génesis recuerda la de la epopeya de Gilgamés (XI.vi) que le arrebata el árbol de la vida que el personaje había conseguido. Sostiene también que la serpiente en el relato bíblico quiere dañar al hombre con su astucia falaz y es envidiosa del hombre. En el relato, afirma, se podría leer una crítica a los cultos cananeos de la fertilidad en los cuales la figura de la serpiente tenía su lugar. Cf. también, en esta línea, T. PRÖPPER, Theologische Anthropologie, p. 934. Sin embargo, creo que el relato bíblico no abunda en descripciones sobre ella y desaparece de la escena tras el castigo sin dejar más huellas. Ateniéndonos al texto, no se podría decir que ella obra por envidia. El acento está puesto sobre su astucia. El relato es más que parco en su caracterización de la serpiente. La crítica a los cultos cananeos no es tampoco, a mi juicio, una cuestión evidente.

18 Cf. J.-L. SKA, I/ cantiere, p. 39: "Il nostro racconto non appartiene neanche al genere letterario delle fiabe. I personaggi, ad esempio, portano nomi e, messo a parte il serpente dotato della parola, i tratti fiabeschi sono molto limitati."

19 Cf. J. A. SAYÉs, Teología, p. 391. 


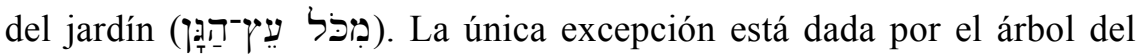

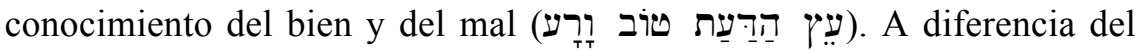
árbol de la vida, que es un motivo extendido, el del conocimiento del bien y del mal es "totalmente desconocido en cercano oriente antiguo, así como además, en el resto de la Biblia". ${ }^{20}$ Esta prohibición divina está acompañada con una amenaza durísima: su transgresión implicará

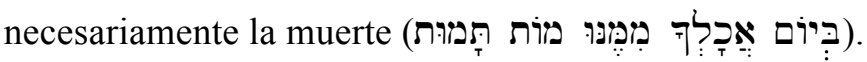

La serpiente lo hace, sin embargo, con un rodeo y no reproduce la orden dada por Dios: abre el dialogo insinuando que Dios les habría prohibido comer de cualquier árbol del jardín:

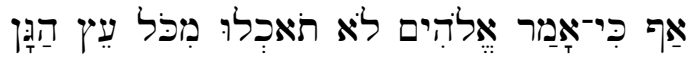

La inexactitud le ofrece la oportunidad a la mujer aclarar: les está permitido comer de todo árbol, con la única excepción del árbol puesto

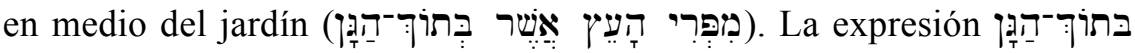
remite a Gn 2,9 donde el narrador describe cómo YHVH hace brotar toda clase de árboles deleitosos y coloca en "medio del jardín" tanto el árbol de la vida (עִ הַחַי הַיים) como el árbol del conocimiento del bien y del mal

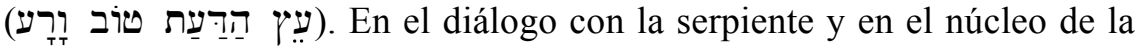
trama del relato se sobreentiende sólo el árbol del conocimiento del bien y del mal. Ello, además de las dificultades que plantea Gn $2,9,{ }^{21}$ ha llevado a algunos a sostener que la mención en el texto del árbol de la vida es obra de un redactor posterior. ${ }^{22}$ A juicio de Ska, la propuesta no es concluyente y puede explicarse narrativamente: el árbol de la vida reaparece al final cuando lo exige la trama. ${ }^{23}$

20 J.-L. SKA, // cantiere, p. 26.

21 Cf. J.-L. SKA, I/ cantiere, pp. 44-47.

22 Cf. J. C. GeRTZ, «Von Adam zu Enosch. Überlegungen zur Entstehungsgeschichte von Gen 2-4», en M. WITTE (Hg.), Gott und Mensch im Dialog. Festschrift Otto Kaiser zum 80. Geburtstag (BZAW 345/1), Berlin - New York, 2004, pp. 228-231; M. WITTE, Die biblische Urgeschichte, p. 81; J.-L., SKA, II cantiere, p. 47 n. 17.

23 Cf. J.-L. SKA, // cantiere, pp. 47-48. Al respecto cf. también A. VAN DER KOOIJ, Paradise, p. 16; T. METTINGER, The Eden Narrative. A Literary and Religio-historical Study of Genesis 2-3, Winona Lake, Indiana, 2007, pp. 5-10; J. KRISPENZ, «Wie viele Bäume braucht das Paradies? Erwägungen zu Gen. ii. 4b-iii 24», en VT 54 (2004), pp. 301-318. 
El centro de la incitación de la serpiente lo constituye lo dicho en Gn 3,5: el día en que comieren del fruto del árbol prohibido se les abrirán

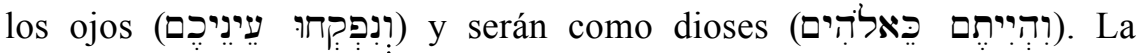
naturaleza de esta semejanza divina aparece inmediatamente precisada en el mismo versículo con una aposición: luego de comer, serán

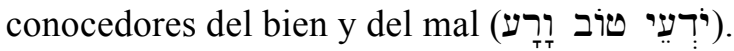

Es en este punto donde se decide, en cierto modo, el sentido del texto. Tradicionalmente se ha visto en este versículo aquella desobediencia de los primeros padres que ha acarreado la muerte y la existencia marcada por el peso de la finitud. Se trata, según esta interpretación, del primer acto de rebeldía del ser humano que pretende tan soberbia como de hecho impotentemente- ocupar el lugar de Dios. El ser humano no se contenta con su condición de creatura. He aquí el pecado original: un atentado contra la soberanía única de Dios, nacido de la soberbia humana.

Un análisis atento del texto permite, sin embargo, orientarnos hacia otra dirección. El diálogo entre la serpiente y la mujer junto con la caída siguiente no pretenden relatar el origen del pecado sino la paradójica condición del ser humano: a pesar de ser conocedor del bien y del mal, semejante a los dioses, no es inmortal. La interpretación que aquí proponemos del texto puede sintetizarse así: si bien a nivel intradiegético, el diálogo entre el más astuto de los animales del campo y la mujer aparece como un juego de seducción (cf. Gn 3,13), el contenido del mismo no es una tentación a lo no debido, sino una constatación de lo dado. ${ }^{24} \mathrm{El}$ análisis siguiente intenta ponerlo de manifiesto.

\section{1 "Se les abrirán los ojos"}

24 Sugestivamente dice E. A. RoBBINS, The Storyteller and the Garden of Eden, Eugene, Oregon, 2012, p. 14 que el texto no narra la caída del hombre sino su elevación a la condición de ser poco menos que un dios. En línea semejante se expresa A. SCHÜLE, Prolog, p. 158: "Insofern erscheint es einseitig, Gen 2-3 lediglich als Ätiologie der Daseinsminderung des Menschen zu beschreiben; sie ist mit gleichen Recht eine Ätiologie der Daseinssteigerung durch Weisheit." Sin embargo, no podría dejar de matizar su conclusión: "Thema von Gen 2-3 ist die Weisheit und ihre ambivalenten Folgen." 
Hemos visto que la serpiente contradice la explicación de la mujer. Lejos de morir, ${ }^{25}$ el comer del fruto del árbol prohibido por Dios traerá consigo que se les abran los ojos. A diferencia de lo que se afirma habitualmente, no se trata aquí de una mentira o de un engaño por parte de la serpiente ya que ello es lo que se cumplirá cabalmente en el relato. La serpiente revela que Dios mismo sabe que se les abrirán los ojos (cf. Gn 3,5). El narrador relata en Gn 3,7 que la serpiente tenía razón, según un esquema de anuncio y cumplimiento: en lugar de morir, tras comer del

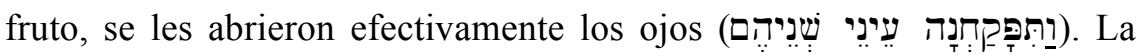
aseveración de la serpiente no era falsa. Signo de ello es que el varón y la mujer perciben ahora que están desnudos, condición que previamente no les avergonzaba (cf. Gn 2,25).

La expresión "abrir los ojos" aparece con cierta frecuencia en la Escritura hebrea y designa generalmente, en relación con el ser humano, una realidad o situación positiva (cf. p. e. Gn 21,19; 2 Re 4,35; 6,17.20; Pr 20,13; Is 35,$5 ; 42,7) .{ }^{26}$ La expresión es una metáfora que se refiere a la comprensión y al entendimiento. ${ }^{27}$

Desde el punto de vista del narrador, el que se hayan abierto los ojos del varón y de la mujer, si bien acontece como una transgresión dentro de la trama del relato, es una realidad y no una soberbia pretensión inalcanzable.

\section{2 "Serán como dioses"}

25 F. GIUNTOLI, Genesi, p. 102 sugiere que en realidad la advertencia de muerte se verifica en la separación de la intimidad y de la cercanía con Dios. "Essi, infatti, si nasconderanno dalla vista del Creatore (cfr. v. 8), come, di fatto, saranno da Lui espulsi dal giardino di 'Eden (cfr. vv. 23-24), venendo così a perdere tutte le prerogative provenienti dalla sua vicinanza e intimità (cfr. vv. 16-19). Questa, dunque, era la morte di cui Dio parlava (cfr. 2,17b) e che, puntualmente, si è verificata." No considero concluyente esta interpretación: la muerte anunciada por Dios no se verifica y la serpiente ha dicho, en este caso, la verdad. Plantearse la necesidad de "defender" a Dios por ello no forma parte del interés del texto y tampoco debería serlo para el exégeta.

26 Incluso se ha argumentado que la expresión de Lc 24,31 alude a aquella del texto del Génesis. Cf. D. C. ORTLUND, «"And their eyes were opened, and they knew". An inter-canonical note on Luke 24:31», en JETS 53, 4 (2010), pp. 717 728.

27 Cf. Z. ZeVIT, Garden of Eden, p. 169. 


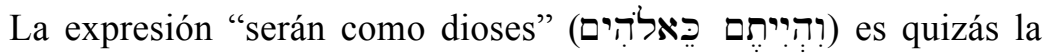
que más ha influido para llegar a la interpretación corriente del texto, según la cual en los orígenes de la historia el ser humano ha pretendido soberbiamente ocupar el lugar de Dios, núcleo del pecado original.

Un texto que se mueve en este horizonte es el oráculo contra el rey de Tiro (Ez 28,1-10). Allí el profeta recrimina al monarca el engreimiento

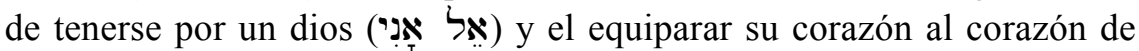

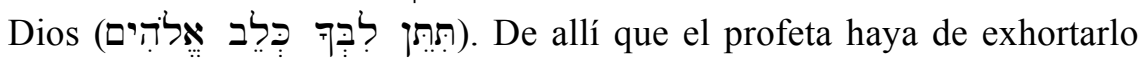
vehementemente a reconocer su condición: el rey de Tiro es hombre y no Dios (Ez 28,2). El hecho de que el segundo oráculo de este texto profético (Ez 28,11-19) describa su caída, aluda al jardín de Edén (Ez 28,13; cf. también Gn 2,10 y Ez 47,1ss ${ }^{28}$ y pueda considerarse un texto paralelo a lo narrado en el libro del Génesis, ${ }^{29}$ podrían sugerir que también en nuestro relato debería verse una actitud semejante por parte del hombre: una pretensión indebida e impotente de condición divina.

Sin embargo, las innegables semejanzas no anulan las grandes diferencias, dado que la cercanía de los textos no puede explicarse como una dependencia literaria en sentido estricto, sino como la inspiración común en una mitología preexistente. ${ }^{30}$ Una de las diferencias más notables entre ambos textos y que, a mi juicio, supone un elemento fundamental es la manera de percibir la usurpación de la condición divina. Mientras que en el oráculo contra el rey de Tiro es claro que su pretensión de ser dios es abiertamente criticada por el profeta en Ez 28,2

28 Un tratamiento más detallado del tema puede verse en T. METTINGER, The Eden Narrative, pp. 85-98.

29 Para C. Westermann, Genesis, p. 285 por ejemplo, Ez 28, 13 es "eine exakte Parallele zu dem Vorkommen von Eden in Gn 2-3", citado en A. Dos SANTOS VAZ, $A$ Visão das Origens em Génesis 2, 4b-3,24. Coerência temática e Unidade Literária, Lisboa, 1996, pp. 161-163. Éste último autor enfatiza los elementos de desemejanza entre los dos textos.

30 Es certera la observación de B. VAWTER, On Genesis: A New Reading. New York, 1977, p. 68 según la cual Ez 28, 11-19 es "undoubtedly the closest parallel in the Hebrew Bible to chapters 2-3 of Genesis. It is not that either passage depends on the other, but that both have drawn on a common mythology from which the one has appropriated some of the details, the other some of the rest, and in a few instances the details are the same". Cf. A. SCHÜLE, Prolog, pp. 156158. Este hecho, un trasfondo común que no implica una dependencia directa entre textos no parece ser tenido en cuenta por A. VAN DER KOOIJ, Paradise, pp. 8-9 cuando plantea el motivo de los jardines. 


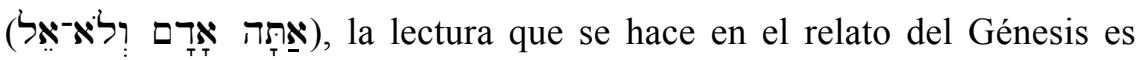
diversa. Allí se da por hecho que el ser humano ha alcanzado esa condición divina. Si bien tendrá que pagar las consecuencias de su acción, no hay ningún intento de llamarlo a lugar o a reconocer que es solamente un hombre y no dios. Incluso el narrador llega al extremo de poner esta constatación en los labios del mismo YHVH Dios en Gn 3,22. Se trata de una percepción de la realidad y corresponde aquello que la serpiente había dicho a la mujer en Gn 3,5. La correspondencia entre la afirmación de la serpiente y la constatación de Dios lo deja claro. Según la serpiente, Dios sabía que en el momento de comer el fruto del árbol prohibido se les abrirían los ojos y que llegarían a ser como Dios, en cuanto conocedores del bien y del mal:
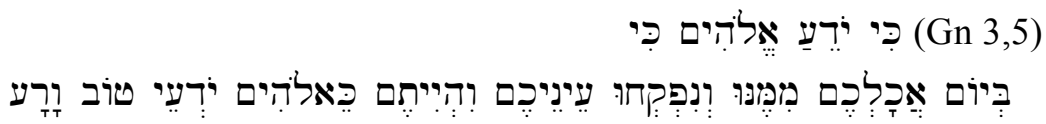

El que ello no haya sido una mentira o un engaño por parte de la serpiente queda claramente expresado con las palabras del mismo Dios, quien constata que ello se ha verificado en verdad $(\mathrm{Gn} 3,22)^{31}$ :

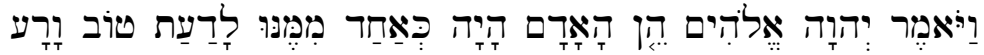

La única precaución que cabe ahora, es evitar que "también" (ם el ser humano se apropie de la inmortalidad, extendiendo su mano y tomando el fruto del árbol de la vida (cf. Gn 3,22).

Esta afirmación de YHVH puede interpretarse como una expresión análoga a lo dicho por Dios en el relato sacerdotal $(\mathrm{Gn} 1,26) .{ }^{32}$ Allí Dios

31 Cf. M. ARneth, Durch Adams Fall ist ganz verderbt... Studien zur Entstehung der alttestamentlichen Urgeschichte (FRLANT 217), Göttingen, 2007, p. 141. La

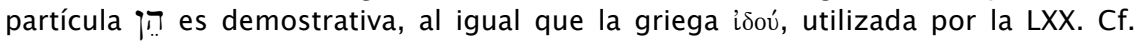
también para el tema R. W. L. MOBERLY, «Did the serpent get it right?», en JTS N.S. 39 (1988), pp. 1-27; A. VAN DER KOOIJ, Paradise, p. 17.

32 Se ha propuesto que el relato del Edén sería un correctivo al sacerdotal. La versión no sacerdotal precisaría y corregiría la noción de imagen divina en el hombre de la primera. Así por ejemplo, A. SCHÜLE, Prolog, pp. 161-165; id., >Image of God<, 20: "Im Unterschied und, literargeschichtlich, in kritischer Auseinandersetzung mit Gen 1 betont Gen 2f. aber auch, worin der Mensch nicht »nur « Gottes Ebenbild ist: in seinem Streben nach Weisheit und Unsterblichkeit sowie in der Liebe zwischen Mann und Frau." No convencen todos sus argumentos y son posibles otras explicaciones. Cf. J. C. GERTZ, "The Formation of the Primeval History», en C. Evans / J. N. Lohr / D. L. PeTERSEN (eds.), The Book of Genesis. Composition, Reception and Interpretation, Leiden - Boston, 2012, pp. 107-136, 116-118. Con este último autor, me inclino a considerar los dos relatos como independientes y diversos, sin que resulte evidente que el relato del Edén pretenda 
decide solemnemente hacer al ser humano según la semejanza divina:

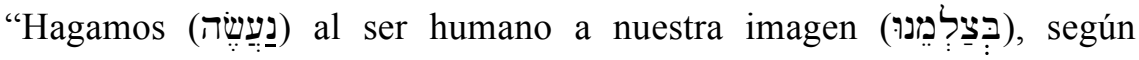

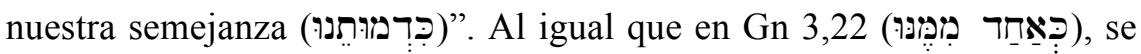
hace aquí también uso del plural. ${ }^{33}$ La concepción de una creación según la semejanza divina aparece también en los versos del salmista. Frente a la pregunta acerca de quién es el hombre (Sal 8,6), el poeta constata que el ser humano es apenas un poco menor que los dioses o, también, que

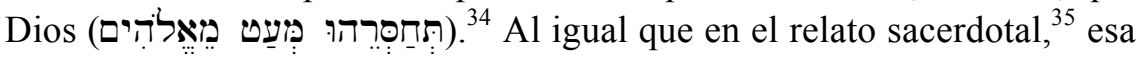
condición está en cierta relación con su dominio sobre lo creado: sobre las ovejas y bueyes, las bestias del campo, las aves del cielo y los peces del mar (Sal 8,7-9). Según Barbiero, el relato sacerdotal constituye su trasfondo. ${ }^{36}$

A los tres textos acomuna la idea de semejanza divina. Difieren ciertamente en el origen de la misma. Mientras que en relato sacerdotal de la creación y en el salmo 8 ella forma parte del plan maravilloso de Dios, en la trama narrativa no sacerdotal del Génesis ella se debe a la "usurpación" del hombre. Además, si en los otros textos la semejanza divina está puesta en relación, de alguna manera, con la soberanía del hombre sobre el resto de la creación (cf. Gn 1,26.28; Sal 8,7-9), en el relato "prometeico" se vincula con el motivo del conocimiento del bien y del mal, si bien la idea del dominio sobre la creación aparece cuando el

corregir al sacerdotal.

33 Cf. M. ARNETH, Durch Adams Fall, 141 n. 124; pp. 144-145. Cf. también H. GUNKEL, Genesis, Göttingen ${ }^{9} 1977$, p. 24 . El plural, como es sabido, no insinúa la Trinidad de personas como han interpretado algunos Padres sino que se trata probablemente de un plural deliberativo. Cf. J. L. SICRE, El Pentateuco. Introducción y textos selectos, Buenos Aires, 2004, p. 85.

34 G. BARbiero, II regno di JHWH e del suo Messia. Salmi scelti dal primo libro del Salterio, Roma, 2008, p. 121 sostiene que la expresión אליהים no debe entenderse como "dioses" en plural, sino en singular como "Dios". Tampoco ha de interpretarse en el sentido de ángeles, como lo ha hecho la LXX o Hb 2,7. Para ello,

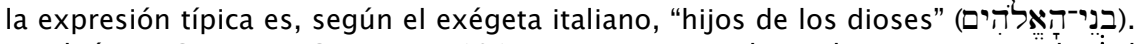
También F. GIUNTOLI, Genesi, p. 101 acepta que pueda traducirse en singular." El Targum lo hace en plural, en el sentido de ángeles.

35 Sobre diversas interpretaciones de la imagen divina, cf. J. L. SICRE, Pentateuco, pp. 85-86.

36 G. Barbiero, // regno, p. 123. Cf. también p. 142. Sobre las diferencias, cf. A. SCHÜLE, Prolog, pp. 117-121. 
hombre recibe la misión de dar nombre a las demás creaturas (Gn 2,1920).

Ni en el relato sacerdotal ni en el salmo 8 aparece explícitamente la problemática de la mortalidad del hombre. Ella es drama y patrimonio de la segunda narración cuando YHVH pone guardia al árbol de la vida. En la teología sacerdotal parece darse por connatural que Adán muera, tras haber engendrado a su imagen y según su semejanza, a su primer hijo Set -no Caín como en el relato no sacerdotal ${ }^{37}$ - así como también a hijos e hijas (Gn 5,1-5). Hay muchos textos bíblicos que dan por supuesta esa mortalidad del hombre (Gn 15,15; 25,8; 35,29, 49,29.33; Sal 89,48-49; Jb 14,2). ${ }^{38}$ Como veremos, también el relato no sacerdotal puede entenderse en esta forma.

El vínculo entre pecado y muerte es mucho más tardío. Muchos autores constatan además que la interpretación de la muerte como consecuencia de un pecado es más bien marginal en la Escritura veterotestamentaria. ${ }^{39}$ Ello está en relación con el origen tardío del relato no sacerdotal. No se lo utiliza para explicar la universalidad del pecado ${ }^{40}$ y parece casi desconocido para gran parte de los testimonios bíblicos: ni la salmodia del Primer Templo ni la literatura profética alude a lo acontecido en el relato ni se lo emplea para llamar a la conversión o para exhortar:

37 Cf. J. L. SICRE, Pentateuco, p. 74: "Después de hablar detenidamente de Caín y Abel, en 5,3, se da por supuesto que el primer y único hijo de Adán es Set." Cf. también J. C. GerTZ, Primeval History, pp. 118-124.

38 Cf. J. L. RUIZ DE LA PEÑA, La pascua de la creación (BAC Manuales 16). Madrid, 1996, p. 59, si bien el autor acentúa otros aspectos y no deja entrever suficientemente la pluralidad de miras que conviven en la Escritura. No se puede simplemente decir que se trate de un "progreso" de la revelación: un primer estadio aceptaría el hecho de la muerte sin más y con el crecimiento de la revelación se habría llegado a barruntar su causa. Más bien habría que decir que en la Escritura conviven diversas afirmaciones sobre la realidad de la muerte. Pretender armonizarlas sería tan factible como tratar de hacer lo mismo con los dos relatos de la creación.

39 Lo sintetiza I. Gous, Snakes and ladders, p. 114: "The first misunderstanding is that Genesis 2 and 3 is a decisive text for the Bible and that it states the premise for all that follows. To the contrary, says Brueggemann: it is an exceedingly marginal text with no clear reference to it in the rest of the Old Testament." También F. GARCIA LÓPEZ, Fundamentos, p. 191.

40 Cf. T. PRÖPPER, Theologische Anthropologie, p. 932 afirma que el relato sacerdotal no comenta el relato de la caída. Menciona solo en 6,1 la realidad del pecado sin preocuparse del cómo. 
"Isaías, que predicó durante casi cuatro décadas alrededor del 742701 a.C. podría haber dicho: 'Ustedes no entienden, ustedes no escuchen, precisamente como Adán -o en realidad, de Eva'. Pero no lo hizo. En su lugar, él dijo: 'Conoce el buey a su dueño y el asno el pesebre de su amo, pero Israel no me conoce, mi pueblo no discierne' (Is 1,3)."41

La confesión de los pecados en Neh 9,16-31, compuesta probablemente en el siglo $\mathrm{V}$ a. C., no contiene ninguna asociación con la historia del jardín sino que comienza con el éxodo. ${ }^{42}$ Ello no deja de ser significativo. J.-L. Ska sostiene que el relato de Gn 2-3 es conocido con seguridad sólo en época tardía, más helenística que persa. ${ }^{43}$ Es en esta época donde quizás se establezca el vínculo entre pecado y muerte, originalmente no contenido en la lógica dramática del relato.

\subsection{El conocimiento del bien y del mal}

La interpretación habitual de la expresión "conocer el bien y el mal", de acuerdo con una precomprensión del texto aparece meridianamente clara en una de las encíclicas más importantes sobre la enseñanza moral de la Iglesia:

“Leemos en el libro del Génesis: «Dios impuso al hombre este mandamiento: "De cualquier árbol del jardín puedes comer, mas del árbol de la ciencia del bien y del mal no comerás, porque el día que comieres de él, morirás sin remedio"» (Gn 2, 16-17). Con esta imagen, la Revelación enseña que el poder de decidir sobre el bien y el mal no pertenece al hombre, sino sólo a Dios. El hombre es ciertamente libre, desde el momento en que puede comprender y acoger los mandamientos de Dios. Y posee una libertad muy amplia, porque puede comer «de cualquier árbol del jardín». Pero esta libertad no es ilimitada: el hombre debe detenerse ante el árbol de la ciencia del bien y del mal, por estar llamado a aceptar la ley moral que Dios le da. En realidad, la libertad del hombre encuentra su verdadera y plena realización en esta aceptación. Dios, el único que es Bueno, conoce perfectamente lo que es bueno para el hombre, y en virtud de su mismo amor se lo propone en los mandamientos. La

41 Z. ZeVIT, Garden of Eden, p. 19. Cf. pp. 20-22.

42 Cf. Z. ZeVIT, Garden of Eden, pp. 6-7; 21.

43 Cf. J.-L. SKA, // cantiere, pp. 24-25. Cf. también A. SCHÜLE, Prolog, p. 160 n. 429. 
ley de Dios, pues, no atenúa ni elimina la libertad del hombre, al contrario, la garantiza y promueve. Pero, en contraste con lo anterior, algunas tendencias culturales contemporáneas abogan por determinadas orientaciones éticas, que tienen como centro de su pensamiento un pretendido conflicto entre la libertad y la ley. Son las doctrinas que atribuyen a cada individuo o a los grupos sociales la facultad de decidir sobre el bien y el mal: la libertad humana podría «crear los valores» y gozaría de una primacía sobre la verdad, hasta el punto de que la verdad misma sería considerada una creación de la libertad; la cual reivindicaría tal grado de autonomía moral que prácticamente significaría su soberanía absoluta." 44

El conocimiento del bien y del mal se interpreta aquí como el poder de decidir sobre el bien y el mal y con ello, la pretensión indebida de soberanía absoluta por parte del ser humano. El pecado original del hombre ha sido precisamente ese acto de rebeldía, dado que este poder de determinar el bien y el mal pertenece sólo a Dios. Muchos comentarios parten de este mismo supuesto. ${ }^{45}$ Sin embargo, un examen atento de la expresión hebrea desautoriza esa interpretación preconcebida y permite arribar a un significado diverso. No es en modo alguno evidente que el verbo "conocer" (ירָיע) junto con la expresión polar "bien y mal" (טוֹב רָרע) tenga el sentido de "decidir" arbitrariamente sobre ellos. En el libro del profeta Isaías se habla más bien de "llamar bien al mal y mal al

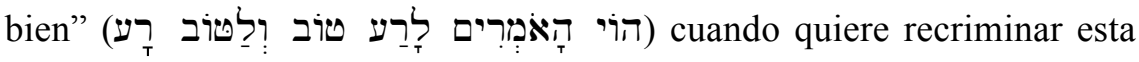
actitud (Is 5,20). Por el contrario, en expresiones análogas tiene una connotación positiva: el sacerdote debe discernir entre animales y le

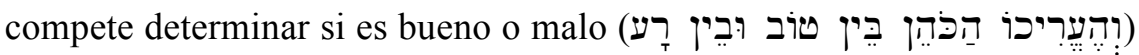
para que puedan ser ofrecidos a YHVH (Lv 27,14); en el discurso de

44 JuAn Pablo II, Carta Encíclica Veritatis Splendor sobre algunas cuestiones fundamentales de la enseñanza moral de la Iglesia, 6 de agosto de 1993, n. 35.

45 El comentario de la Biblia de Jerusalén de 42009 se expresa así: "Esta «ciencia» es un privilegio que Dios se reserva y que el hombre usurpará por el pecado, 3, 5.22. no es, pues, ni la omnisciencia, que el hombre caído no posee, ni el discernimiento moral, que ya poseía el hombre inocente y que Dios no niega a su criatura racional. Es la facultad de decidir uno por sí mismo lo que es bueno y lo que es malo, y de obrar en consecuencia: una reclamación de autonomía moral, por la que el hombre no se conforma con su condición de criatura, ver Is 520 . El primer pecado ha sido un atentado a la soberanía de Dios, un pecado de orgullo. Esta rebelión se ha expresado concretamente con la transgresión de un precepto impuesto por Dios y representado en la imagen de la fruta prohibida." Cf. también J. A. SAYÉs, Teología, pp. 390-391. 
Moisés se menciona a los niños que aún no distinguen el bien y el mal pero que serán los que entrarán en la Tierra (Dt 1,39); cuando Barzilay se presenta ante el rey David no quiere seguirlo a Jerusalén objetando no considerarse capaz de conocer el

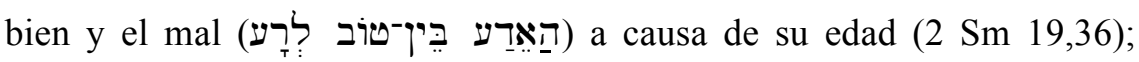
Salomón le pide a YHVH un corazón que escuche para poder juzgar al

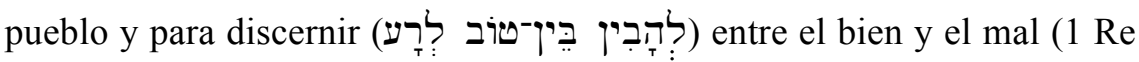
3, 9); en el signo del Emmanuel se alude a la capacidad de aprender

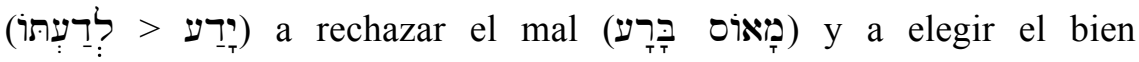

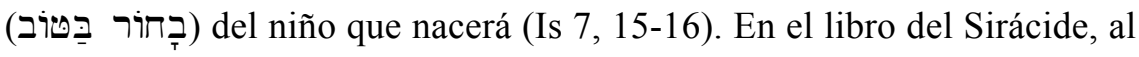
hablar de la creación del hombre, no sólo se menciona su origen de la tierra y el designio divino de hacerlo volver allí sin que aparezca mención alguna del pecado (Eclo 17,1-2) sino que también, se hace mención de la imagen divina (Eclo 17,3) y en el contexto de la descripción de la inteligencia humana (Eclo 17,6), se atribuye a Dios el haberle mostrado

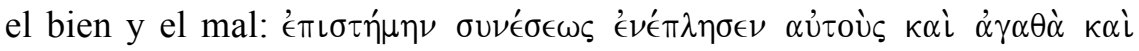

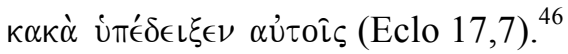

En todas estas expresiones el conocimiento o discernimiento del bien y del mal es la condición deseable del ser humano ${ }^{47}$ y no cabe establecer una diferencia entre una supuesta sabiduría legítima y otra contraria a la voluntad divina. ${ }^{48}$ "No es una falsa sabiduría la que el

46 Las semejanzas entre el relato de Gn 2-3 y Eclo 17 han sido puestas de manifiesto por E. OTTO, «Die Paradieserzählung Genesis 2-3. Eine nachpriestliche Lehrerzählung in ihrem religionshistorischen Kontext», en A.A. DIESEL et al. (Hgg.), "Jedes Ding hat seine Zeit...". Studien zur israelitischen und altorientalischen Weisheit. Diethelm Michel zum 65. Geburtstag (BZAW 241), Berlin - New York, 1996, pp. 167-192, 182-183, citado en A. Schüle, Prolog, p. 166. A juicio del exégeta, el relato une pensamiento sapiencial tardío con la teología de la alianza. Es discutible que esta teología de la alianza esté en el trasfondo del relato.

47 Cf. R. AlberTZ, «,Ihr werdet sein wie Gott“ (Gen 3,5)», en F. CRÜSEMANN / C. HARDMEIER / R. KESSLER (Hgg.), Was ist der Mensch...? Festschrift H. W. Wolff zum 80. Geburtstag, München, 1992, pp. 11-27, 13; K. SCHMID, «Die Unteilbarkeit der Weisheit. Überlegungen zur sogenannten Paradieserzählung Gen $2 f$. und ihrer theologischen Tendenz», en ZAW 114 (2002), pp. 21-39, 29; A. SCHÜLE, Prolog, p. 167.

48 E. NARDONI, Género literario y teología, pp. 78-79 establece una diferencia entre los textos que he acercado aquí: "Pero hay que distinguir dos tipos de sabiduría: la sabiduría animada por el temor de Dios y la sabiduría de autonomía moral. La primera era considerada como un atributo divino participable. Tres veces 
hombre adquiere, sino de hecho aquella que lo hace un ser semejante -al menos en lo que concierne a la capacidad de conocer- a un Dios $(3,22) . "{ }^{49}$ De allí que se pueda suscribir la afirmación de Schüle: "Sea cual sea el objetivo que persigue en verdad la serpiente, ella no engaña al hombre con ninguna palabra." 50

Ello queda corroborado ulteriormente por el mismo narrador que, hablando desde la perspectiva de la mujer, sostiene que el árbol era bueno

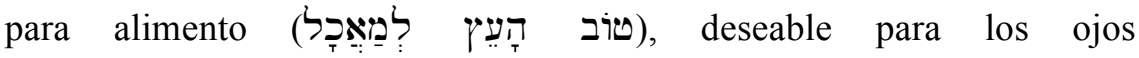

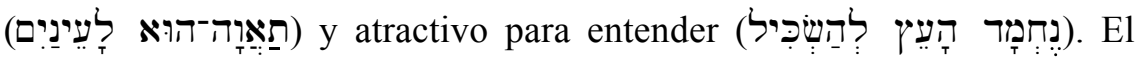

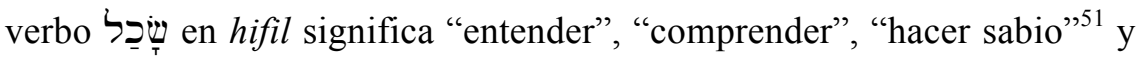
la raíz aparece vinculada a la sabiduría en varios textos (p.e. Dt 32,29; 2 Cro 30,22; Neh 8,13; 9,20; Jb 34,27; 34,35; Sal 2,10; 14,2; 32,8; 53,3;

se dice del rey David que era como el ángel de Dios por su conocimiento del bien y del mal. En dos de ellas se trata de la capacidad de David de dar la sentencia justa y establecer el orden en una situación conflictiva (2 Sam 14:17; 19:27). En el otro caso, se trata de un conocimiento amplísimo con una perspicacia afinadísima que le permite al rey descubrir los trucos y engaños de sus súbditos (2 Sam 14:20). Salomón, por su parte, pidió al Señor la sabiduría que incluía la capacidad para distinguir el bien del mal y establecer la justicia para gobernar rectamente al pueblo (1 $\operatorname{Re} 3,9.11$ ). La sabiduría de David y la que pedía Salomón iban acompañadas del temor de Dios. En cambio, la sabiduría que ofrece el árbol de la ciencia del bien y del mal es una sabiduría de autonomía moral'. Una interpretación semejante puede verse también en J. BLENKINSOPP, The Pentateuch. An Introduction to the first Five Books of the Bible (Anchor Bible Reference Library), New York, p. 67, citado en A. SCHÜLE, Prolog, pp. 165-168. Sin embargo, una tal distinción no está, a mi juicio, fundamentada en un análisis del texto y se debe más bien a la precomprensión con la que se accede al texto bíblico. La lectura que aquí ofrezco intenta hacer justicia a la trama del relato sin proyectarle aquello que "debería" decir.

${ }^{49}$ A. SChÜle, Prolog, p. 167. Cf. también M. ARneth, Durch Adams Fall, p. 125; O. H. STECK, «Die Paradieserzählung. Eine Auslegung von Gen 2,4b-3,24», en id., Wahrnehmungen Gottes im Alten Testament (TB 70), München, 1982, pp. 9-116, 29 n. 43; R. AlBERTZ, „Ihr werdet sein wie Gott“, p. 26; E. OTtO, Paradieserzählung, p. 175; id., «Woher weiß der Mensch um Gut und Böse? Philosophische Annäherungen der ägyptischen und biblischen Weisheit an ein Grundproblem der Ethik», en S. BEYERLE et al. (Hgg.), Recht und Ethos im Alten Testament - Gestalt und Wirkung. Festschrift H. Seebass, Neukirchen-Vluyn, pp. 199, 207-231, 229; K. SCHMID, Unteilbarkeit, p. 27.

50 A. SCHÜle, Prolog, p. 167. De acuerdo a ello, no tienen fundamento en el texto el análisis y las afirmaciones vertidas en T. PRÖPPER, Theologische Anthropologie, pp. 937-938. Se mueve fuera del mundo del relato.

51 Cf. L. KöHLER - W. BAumgartner, The Hebrew and Aramaic Lexicon of the Old Testament. Vol. 2, Leiden - Boston - Köln 2001, p. 1328. (= HALOT). 
106,$7 ; 119,9 ;$ Pr 1,$3 ; 10,19 ; 16,23 ; 19,14 ; 21,16$; Is 41,20; 44,18; Jr 3,15; 9,$23 ; 23,5 ;$ Dn 1,4.17; 9,13.22.25; 11,33; 12,3.10; Am 5,13). Así, por la pluma del narrador que se expresa desde la perspectiva de la mujer, sabemos que el fruto confiere de hecho aquello que promete.

La adquisición de esta sabiduría está ligada al árbol del conocimiento del bien y del mal. Se trata, como ya se ha mencionado, de un motivo desconocido, pero que se vincula con otro conocido $y$ difundido: la búsqueda o el deseo humano de la sabiduría que pertenece a los dioses. ${ }^{52}$ Jaroš ejemplifica con el mito de Adapa, según el cual el dios Ea le ha dado al primer hombre sabiduría pero no inmortalidad. ${ }^{53}$ También en la epopeya de Gilgamés se presenta el conflicto entre sabiduría divina e inmortalidad. Enkidu alcanza sabiduría por medio de la unión sexual con una prostituta del templo. Ella se dirige a él y reconoce esa condición divina: "Eres sabio, Enkidu, eres como un Dios". ${ }^{4}$ Ello, sin embargo, implicará la muerte para Enkidu, quien por su parte maldecirá a la prostituta por haber obrado a sabiendas. ${ }^{55}$

No considero, sin embargo, que la posterior interpretación de Karoš tenga un apoyo suficiente en la trama de nuestro relato. ${ }^{56}$ El autor sostiene que el hombre pretende allí su total autonomía y ello le acarrea no solamente la muerte, sino también el fracaso más estrepitoso: en lugar del conocimiento del bien y del mal al que aspiraba, habría llegado

52 Cf. K. JAROŠ, «Die Motive der heiligen Bäume und der Schlange in Gen 2-3», en ZAW 92 (1980), pp. 204-215, 206-207.

53 Cf. ANET, p. 101: "Wide understanding he had perfected for him to disclose the designs of the land. To him he had given wisdom; eternal life he had not given him". Cf. también A. VAN DER KOOIJ, Paradise, p. 18 que pone en relación la sabiduría divina con la realeza. Como ejemplo veterotestamentario menciona a David (2 Sm $14,17.20)$. El autor destaca que se trata de una vinculación atestiguada en las fuentes mesopotámicas. Sin entrar en la discusión, cabe señalar lo que podría ser un elemento interesante: el relato del Génesis usaría así un elemento de la simbología real pero aplicándola al ser humano. Ello podría ser análogo a lo verificado, según algunos, en el relato sacerdotal: aplica la idea de la imagen de Dios -que pertenece al mundo de la realeza- a todo ser humano.

54 A. HeIDEL, Gilgamesh Epic and Old Testament Parallels. Chicago - London, 1949, p. 22.

55 Cf. K. JAROŠ, Die Motive der heiligen Bäume, p. 206.

56 Cf. K. JAROŠ, Die Motive der heiligen Bäume, p. 207. El hombre comió del fruto del árbol del bien y del mal y fue hecho sabio como Dios pero no pudo comer del fruto del árbol de la vida para ser, además, inmortal como Dios. 
solamente a descubrir su indefensión, expresado en la imagen de percatarse de la desnudez. La sabiduría, a su juicio, seguiría siendo inalcanzable. Sin embargo, por lo dicho anteriormente, considero que el texto del Génesis da por supuesto que el hombre sí alcanza el conocimiento del bien y del mal deseado. Es una realidad y esa es su condición de allí en más. Prueba de ello, a diferencia de lo sostenido por Karoš, es precisamente el descubrirse desnudo, tras haber abierto los ojos. El comer del fruto del árbol implica alcanzar de hecho lo que ese árbol promete. De lo contrario, la simbología del árbol no cumpliría su función. Si el comer del fruto del árbol no implicase el apropiarse de aquello que su nombre designa, hubiese sido innecesario y superfluo, en la lógica del relato, que Dios pusiese una guardia delante del árbol de la vida para impedir que el hombre lo tome.

\section{Las trágicas consecuencias de la "desobediencia"}

Tras la narración de la desobediencia de Adán y de Eva $(\mathrm{Gn} 3,6)$, el narrador certifica que efectivamente se les abrieron los ojos y que así se percataron de que estaban desnudos (Gn 3,7), condición de la que no eran conscientes y que, por tanto, no los avergonzaba (cf. Gn 2,25). En el relato, YHVH no parece saber nada de lo ocurrido hasta que llama al hombre y éste le confiesa su miedo y su desnudez (Gn 3,8-11). Sólo entonces YHVH Dios descubre que han comido del fruto del árbol prohibido: la conciencia de estar desnudos es un signo inequívoco de la transgresión. Se les han abierto los ojos.

Durante el dramático diálogo se definen las responsabilidades: el varón aduce que la mujer que Dios mismo le había dado para que estuviese con él lo ha inducido (Gn 3,12) y ella, a su vez, puede atribuirlo a la seducción de la serpiente (Gn 3,13). Giuntoli da una interpretación moral de la sucesión de acusaciones: entiende que los versículos en cuestión describen la lamentable cadena de des-responsabilización y de auto-justificación que "el pecado intrínsecamente produce en quien lo ha hecho" y de esta manera, prosigue el exégeta italiano, "el hombre adosa a la mujer la culpa de la propia elección de haber comido del árbol a la mujer -casi culpabilizando a Dios de habérsela puesto al lado- mientras 
que la mujer acusa a la serpiente de haberla seducido con el engaño."57 En realidad, antes que dar una interpretación moral, habría que tener en cuenta aquí un aspecto narrativo: las sucesivas explicaciones narran simplemente lo sucedido en el relato. Reproducen fielmente lo que ha sido la trama del acontecimiento y el desenvolvimiento de los hechos.

La sentencia divina de castigo sigue el orden inverso: comienza con la serpiente (Gn 3,14-15), sigue con la mujer (Gn 3,16) y culmina con el varón (Gn 3,17-19). Ya no hay más diálogo sino que es Dios el que exclusivamente hace uso de la palabra. Se trata de versículos fundamentales, porque ellos han sido interpretados literalmente como el castigo histórico que siguió a la desobediencia original. Esta segunda parte del relato que narra el castigo de la transgresión de haber comido del árbol del conocimiento del bien y del mal ha cobrado una repercusión enorme en la interpretación a lo largo de la historia. Tomados al pie de la letra, ellos han sido entendidos como el justo castigo por el pecado terrible del ser humano.

Se ha sostenido que aquí el autor pretende dar una respuesta a la cuestión de la teodicea: el mal presente en el mundo no viene de Dios ni puede atribuirse a su mano. El mal se explicaría a partir de la responsabilidad humana. ${ }^{58}$ Ciertamente el autor establece un vínculo en el interior del relato entre esa "desobediencia" y los males y realidades dolorosas que constata en la vida diaria: la serpiente que repta y su asechanza peligrosa al linaje humano; la fatiga del embarazo, el dolor del parto y el sometimiento de la mujer a su marido; la aridez del suelo y la fatiga del trabajo durante toda la vida del hombre. Se trata de experiencias verificables en la vida cotidiana para las que el autor ofrece una respuesta llamativa: en el mito de aquella desobediencia por la cual el hombre llega a ser como dios se halla la explicación de los dramas que vive y que lo acompañarán hasta el día de su muerte. Ellos son el castigo recibido por haber llegado a ser capaz de discernir y conocer el bien y el mal, atributo originalmente divino.

Cabe aquí llamar la atención sobre un hecho: se trata de un castigo soberanamente impuesto por Dios. La cadena de consecuencias no había sido anunciado en el relato. Éste sólo había mencionado la amenaza de

57 Cf. F. Giuntoli, Genesi, p. 104.

58 Cf. T. PRÖPPER, Theologische Anthropologie, pp. 934-935. 
muerte súbita que, como se verá más adelante, en rigor, no se cumple. La desobediencia no engendra de suyo estas consecuencias que se siguen en el relato. Dado que hubiese podido ser otro o de otra manera, el castigo no es, por tanto, una consecuencia necesaria de la transgresión sino una imposición libre de Dios. Dicho de otra forma: el mal en sus diversas formas se origina -intradiegéticamente hablando- en una maldición

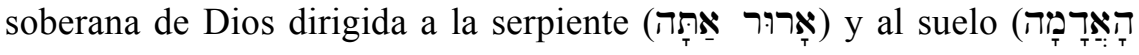

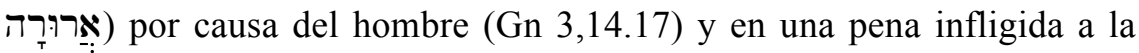
mujer (Gn 3,16).

Por otra parte, es necesario evitar una transposición del castigo descripto en la trama interna del relato al nivel histórico. Ello es un paso indebido. Si la "desobediencia", correctamente interpretada, está en relación con la semejanza divina del hombre que el relato sacerdotal presenta, en cambio, como querido por Dios, entonces ella no puede ser la "causa histórica" de los males descriptos. La trama narra que las realidades dolorosas experimentadas a diario son el castigo divino por el pecado de ser hombre, conocedor del bien y del mal. El hombre paga caro su condición. Algunas observaciones acerca del castigo infligido por Dios a los diversos actores del relato ratifican esta afirmación.

\subsection{El castigo a la serpiente}

Dentro de la trama, YHVH se dirige en primer lugar a la serpiente. Ella no se convierte nunca en su interlocutora ya que no hay ninguna respuesta suya. La serpiente sólo ha hablado con la mujer. La naturaleza del castigo infligido ratifica que la serpiente es vista exclusivamente como una de las creaturas del mundo visible. Como ya se ha mencionado, no es posible ver en ella alusión alguna al diablo.

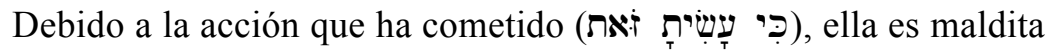

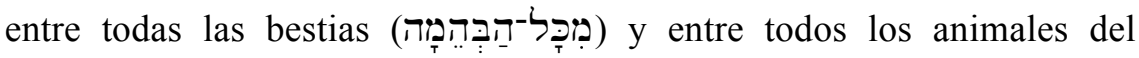

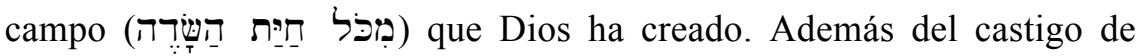

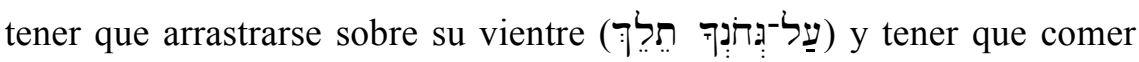

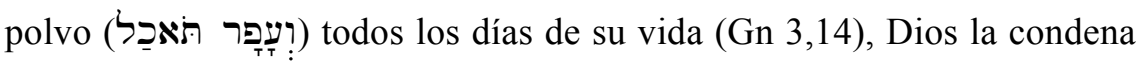
a la enemistad (אירָה) con la mujer y que afectará a ambos linajes

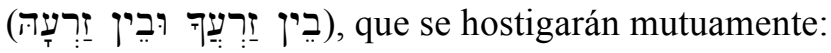

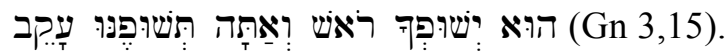


La traducción de este último versículo es compleja. Se trata de una oración coordinada a nivel gramatical, que comienza con el pronombre הוּא como sujeto, referido al linaje de la mujer. A él se atribuye una acción con el verbo שִּף en relación con la cabeza (ראשי) de la serpiente, la misma acción que se atribuye a ésta, segundo sujeto, en relación con el talón (עָ⿳亠䒑八) del linaje humano. El significado es dudoso. ${ }^{59}$ El verbo aparece sólo un par de veces más en la Escritura (cf. Jb 9,17; Sal 139,11) y tiene siempre una connotación negativa.

La interpretación habitual que entiende un "aplastar la cabeza de la serpiente, mientras ésta acecha el talón", con la cual se afirma una superioridad del linaje humano sobre la serpiente, ${ }^{60}$ es sólo conjetural. No puede excluirse, a mi juicio, un significado de hostigamiento recíproco: él acechará/vigilará siempre su cabeza y ella, su talón. De esta forma se concretiza la enemistad mencionada al inicio de la maldición. Así parece haberlo entendido la versión de la LXX que utiliza, siguiendo la letra del

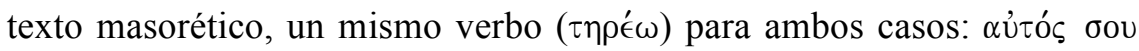

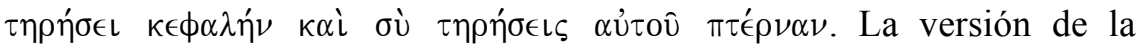
Vulgata, alejándose del hebreo, introduce dos verbos diferentes: ipsa conteret caput tuum et tu insidiaberis calcaneo eius. Ello conlleva una superioridad sobre la serpiente que no aparece clara, a mi juicio, en el texto original. Se trata de una acechanza recíproca permanente -como la adversidad del varón con el suelo mencionado después- y que no permite vislumbrar una primacía humana. Tampoco puede verse un "protoevangelio" ${ }^{61} \mathrm{y}$, mucho menos, de inspiración mariológica. ${ }^{62} \mathrm{La}$

59 Cf. HALOT 2, pp. 1446-1447. Para algunas propuestas, cf. Z. ZEVIT, Garden of Eden, pp. 199-201.

60 En todo caso, si se tratase de una primacía humana, no sería la primacía de un mesías, como parece haberlo sugerido -según algunos- la LXX al usar un

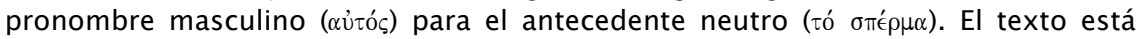
lejos de pensar en términos mesiánicos. Además, tampoco es una supremacía sobre el diablo, dado que sería impensable que fuese el linaje humano quien lo aplasta y no Dios.

61 Se ha afirmado que la LXX, al usar un pronombre masculino en lugar del neutro como debería ser por su antecedente, introduce una interpretación

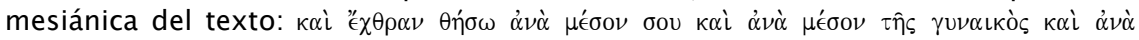

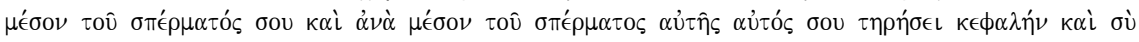

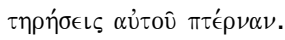

62 La interpretación mariológica se basa en una traducción errónea de la Vulgata en la cual se vierte "ipsa" en alusión a la mujer, mientras que en el hebreo 


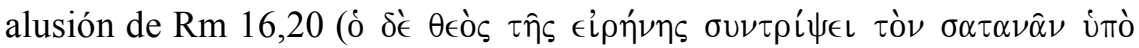

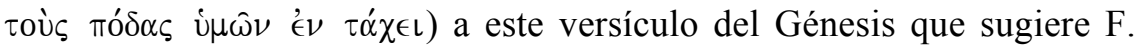
Giuntoli, ${ }^{63}$ está lejos, a mi entender, de ser evidente. No sólo porque Dios mismo es aquí el sujeto y no la estirpe humana como en Gn $3,15,{ }^{64}$ sino

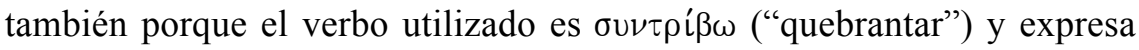
claramente una superioridad que el texto hebreo, en cambio, no deja reconocer.

Si lo aquí expuesto es una interpretación plausible, entonces podría verse en el castigo narrado una explicación del comportamiento habitual, verificable, entre todo ser humano y la serpiente. ${ }^{65}$ En ese caso, el contenido de la maldición divina a la serpiente no desentona de aquel de las sentencias pronunciadas por Dios contra la mujer y el varón.

\subsection{El castigo a la mujer}

La sentencia proferida contra la mujer es la más breve de las tres. ${ }^{66}$ Toca fundamentalmente dos ámbitos: la maternidad y la relación con el varón. Con una construcción enfática, YHVH Dios sentencia que multiplicará el dolor del embarazo de la mujer:

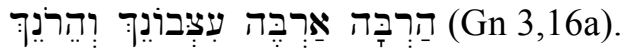

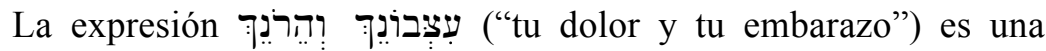
endíadis. El objeto lógico que en la expresión será multiplicado por Dios

es claramente masculino y se refiere al linaje. La lectura mariológica de Ap 12 no es en absoluto segura. De allí que resulte llamativa la afirmación de J. A. SAYÉs, Teología, p. 360. Si es posible que Ap 12 tenga una "cierta correspondencia con Gn 3,15-16", no se puede decir que sea en un sentido mariológico.

63 Cf. F. Giuntoli, Genesi, p. 105.

64 La interpretación que ve al diablo simbolizado en la serpiente y la que ve un anuncio de su derrota se choca también con esta dificultad: en el texto hebreo es el linaje humano -y no una figura mesiánica- el que se confronta con la serpiente. Sería entonces el hombre mismo quien vencería al diablo.

65 Cf. Z. ZEVIT, Garden of Eden, p. 201: "The introduction of the enmity theme in verse 15 may not arise from anything in the narrative. It may simply be tagged onto the story to explain actual human behavior around serpents."

66 Sobre algunos elementos de la composición de las tres sentencias y sus diferencias, cf. M. ARNETH, Durch Adams Fall, pp. 110-117. No todo lo que allí expone y afirma el autor es convincente. 
es evidentemente el dolor, no el embarazo. ${ }^{67}$ Ello es ulteriormente

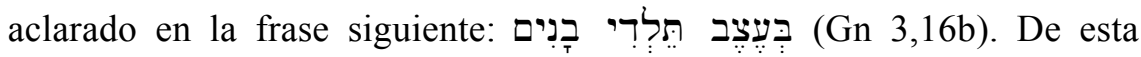
forma, el autor ofrece una etiología de la experiencia conocida del parto doloroso, poniéndola en relación directa con la transgresión narrada. La interpretación "histórica" de este elemento del relato ha llevado a excluir el dolor del parto de María, debido al dogma católico de la inmaculada concepción de la madre de Jesús. Dado que ella "fue preservada de la mancha del pecado original en previsión de los méritos de Cristo" no pudo haber experimentado ningún dolor al dar a luz a su hijo.

La segunda parte de la sentencia pronunciada por Dios afecta la

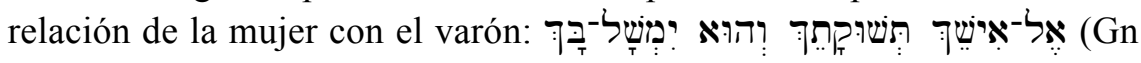
$3,16 c$ ). En la narración, la mujer ha ejercido un cierto dominio sobre él al convencerlo de comer del fruto. En este ámbito se verifica precisamente

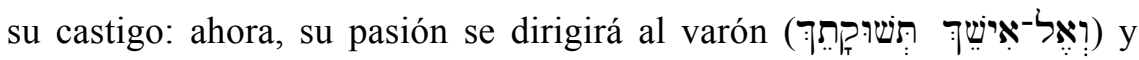

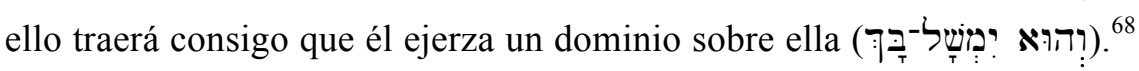
Esta afirmación no deja de ser sorprendente: el autor parece considerar la

67 La LXX no vierte esta endíadis sino que utiliza dos términos que aluden al

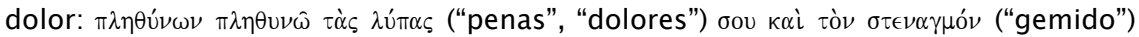
бov. Quizás para evitar la confusión que se seguiría si no se lee la construcción hebrea como endíadis: parte del castigo sería "multiplicar el embarazo". Ello contradiría el mandato divino de multiplicarse. Algunos exégetas no ven la endíadis y tienen que recurrir a otras explicaciones para superar el inconveniente. H. GUNKEL, Genesis, Göttigen, ${ }^{9} 1977$, p. 21 considera que la mención al embarazo no concuerda bien aquí y podría ser una corrupción. La razón de ello es que la multiplicidad de embarazos no puede ser una maldición, ya que para la mujer antigua era una bendición. Para M. ARNETH, Durch Adams Fall, p. 99 n. 9 tiene que ser un agregado posterior.

68 A juicio de A. SCHüLE, Prolog, pp. 196-198 no se trata necesariamente de un dominio. El autor matiza así la expresión. La argumentación, a nuestro juicio, no es totalmente convincente. Parece claro que el contexto de Gn 3,16 hace que la sumisión descripta sea vista como negativa. La equiparación con el dolor del parto es contundente. Además de ello, el autor introduce una interesante observación, si bien ameritaría una discusión amplia. Sostiene que Gn 3,16, leído desde Gn 4,7 implicaría una personificación del pecado como mujer. Ello sería, sin embargo, una interpretación posterior, proyectada al pasaje de la sentencia divina a la mujer. Una tal personificación no está ausente de la literatura sapiencial. También se podría ver que la mujer, si bien lo lleva a la desobediencia, le confiere, no obstante, la sabiduría. Si la relectura propuesta por Schüle del pecado como mujer fuese correcta, habría que deducir también una consecuencia en esa relectura posterior: Gn 3,16 sería casi un "protoevangelio" en el cual se insinuaría el dominio del varón sobre el pecado personificado como mujer. 
sumisión de la mujer al varón como un mal, parangonable a los otros dramas descriptos.

La expresión ("ansia", "pasión”, “deseo") aparece sólo en dos pasajes más en el Antiguo Testamento. ${ }^{69}$ En el diálogo con Caín (Gn 4,7), Dios le advierte que el pecado estará a su puerta y la pasión del

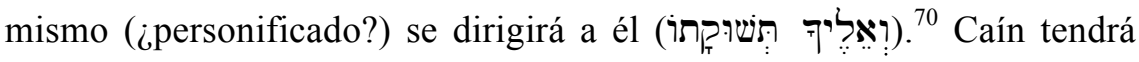

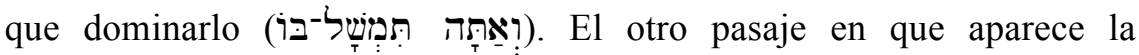
expresión es en el canto de la esposa en el Cantar de los Cantares. Allí ella, describe una relación contraria a la sentenciada en el Génesis:

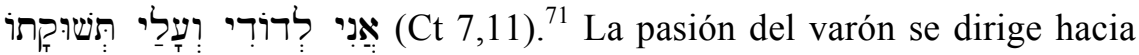
ella. $^{72}$ El contexto amoroso del Cantar de los Cantares difiere claramente del contexto del Génesis.

\subsection{El castigo al varón}

Se trata de la sentencia más extensa del relato y, por la referencia a la muerte, la que ha tenido más relevancia y repercusión en la historia de la teología. La primera afirmación de la sentencia divina está en relación

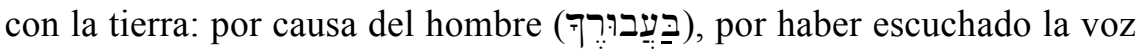
de la mujer en lugar de obedecer el mandato divino y haber comido del

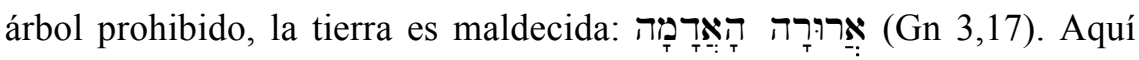
parece recaer, en gran medida, el acento y el peso de toda la sentencia. El contenido o las implicancias concretas de esa maldición se explican a continuación: el hombre -suponiendo ya en los orígenes una sociedad

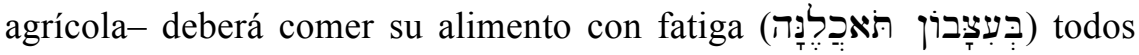

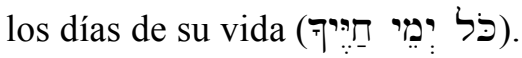

La sentencia tiene semejanzas con las proferidas contra la serpiente (Gn 3,14) y contra la mujer (Gn 3,15). La serpiente deberá comer polvo

69 Para una breve discusión, cf. Z. ZEVIT, Garden of Eden, pp. 210-211.

70 Algunos problemas filológicos de la expresión pueden verse en F. GIUNTOLI, Genesi, pp. 112-113. Una solución atendible propone A. SCHÜLE, Prolog, p. 198.

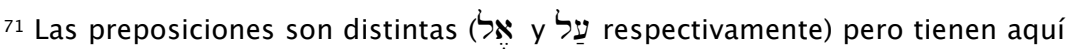
el mismo sentido. Cf. HALOT 2, p. 826.

72 Cf. A. SChüle, Prolog, p. 196; G. Ravası, I/ Cantico dei Cantici. Commento e attualizzazione, Bologna, 1992, p. 595. 


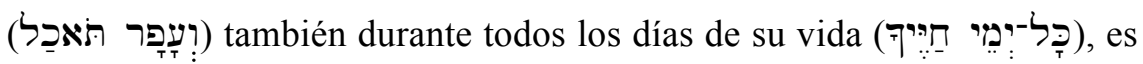
decir, mientras dure su vida. En segundo lugar, así como Dios

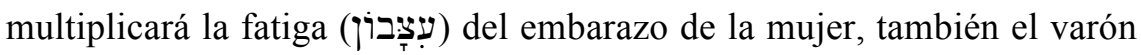
deberá experimentar lo mismo (עִצָּבוֹן) para comer, en el ámbito de su trabajo. A continuación se precisa ulteriormente esa fatiga: la tierra le

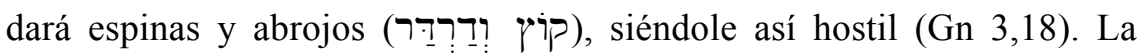
última afirmación que el narrador pone en labios de YHVH Dios insiste sobre la fatiga del comer a través de la idea del sudor del rostro

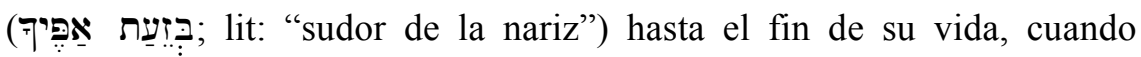
deberá volver a la tierra de la cual había sido tomado (Gn 3,19).

La expresión final sobre el retorno a la tierra no es objeto directo de la sentencia sino que más bien describe el arco temporal de la sentencia: el hombre habrá de luchar contra la hostilidad de la tierra para comer su propio alimento - para subsistir- hasta (עַ) su retorno final a la

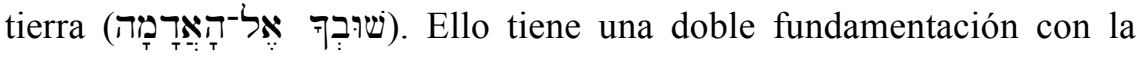
conjunción י: $:$ el hombre vuelve a la tierra porque ha sido tomado de ella

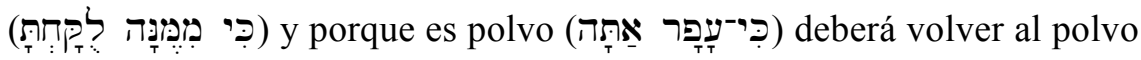

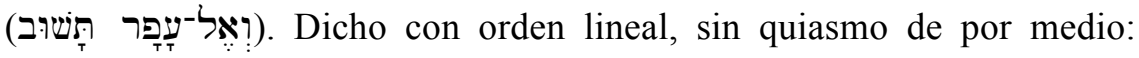
deberá volver a la tierra y retornar al polvo porque ha sido tomada de ella y porque no es más que polvo.

En esta frase nos encontramos con un punto fundamental del pasaje. Para la interpretación habitual, aquí se encuentra el origen histórico de la muerte. Así ha sido entendido ya en textos bíblicos y paracanónicos. Con toda una larga tradición, Tomás de Aquino enseña que el hombre "en estado de inocencia" era inmortal, si bien con una inmortalidad diversa de aquella gloriosa. ${ }^{73}$

Como ya se ha dicho, son muchos los textos escriturísticos que dan por supuesto "serenamente" que el hombre es polvo y por tanto, mortal. ${ }^{74}$ Recordemos que la teología sacerdotal supone que el hombre es mortal desde su origen (cf. Gn 5,1-5). Esta condición es constitutiva del ser

73 Cf. TomÁS de Aquino, Suma de Teología I, q. 97, art. 1.

74 J.-L. SKA, // cantiere, p. 55. 
humano y no se debe a ningún pecado inicial. ${ }^{75}$ Ahora bien, el relato de Gn 3 ipresupone, en cambio, la idea de un hombre inmortal en los inicios? A pesar de la larga tradición que da una respuesta positiva a esta pregunta, un análisis detenido de la trama y del texto consiente la respuesta contraria. ${ }^{76}$

Ya se ha mencionado que la afirmación final de Gn 3,19 no es el objeto de la sentencia divina sino el marco temporal en el cual aquella -la lucha contra la tierra vuelta hostil- se desenvuelve. A ello debemos añadir un breve análisis de la amenaza divina dirigida previamente al varón (Gn 2,17), de la aseveración de la serpiente al respecto $(\mathrm{Gn} 3,4-5)$ y de los hechos ocurridos tras la desobediencia (Gn 3,7).

En la advertencia dirigida al hombre, Dios afirma la inexorabilidad de la muerte en el día mismo en que el hombre comiere del árbol

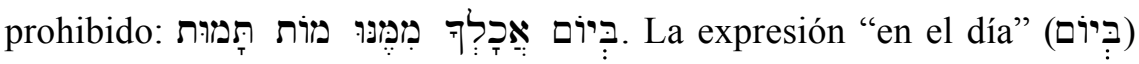
ha sido interpretada muchas veces como un inicio: a partir de entonces el hombre comenzaría a ser mortal, sin que la muerte tuviese que verificarse necesariamente en "ese día". 77

Sin embargo, la expresión admite otra interpretación, quizás más plausible. ${ }^{78}$ Tanto fuera (Gn 2,2) como dentro del relato no sacerdotal (Gn 2,4b), la frase indica un momento puntual y delimitado. Interpretada en este sentido, la advertencia dada por Dios a Adán no implica que él

75 Cf. A. SCHÜLE, Prolog, p. 235; pp. 242-244. Tampoco el relato mitológico de la unión de los hijos de los dioses con las hijas de los hombres parece suponer la inmortalidad. Aquí Dios limita la vida humana a 120 años.

76 Así, por ejemplo, cf. Z. ZEVIT, Garden of Eden, p. 125; A. VAN DER KOOIJ, Paradise, p. 19-20. La afirmación sintética de éste último es pertinente: "The idea that man was created as a mortal being is also basic to Gen. 2-3, since he was formed out of the 'dust of the ground'. The difference between Mesopotamian myths and Gen. 2-3 is that in the latter the decision that man must remain mortal, was made for a particular reason - namely, because man had acquired divine wisdom." También E. NARDONI, Género literario y teología, p. 83 excluye la inmortalidad inicial: "La respuesta, según la sentencia común de los exégetas actuales, es negativa. Una razón es porque Adán según el relato del Génesis no gozó del don de la inmortalidad antes del pecado. La inmortalidad no fue un bien que la humanidad poseyó al comienzo, sino una meta que se debía alcanzar." A mi juicio, sin embargo, podría discutirse la afirmación según la cual la inmortalidad era una "meta a alcanzar". No hay nada en el relato que lo sugiera.

77 Sobre esta discusión, cf. A. VAN DER KOOIJ, Paradise, pp. 4-5.

78 No es tampoco necesario interpretar Gn 2,17b como una glosa, como hace K. JAROŠ, Die Motive der heiligen Bäume, p. 205. 
dejaría ser inmortal y que entonces, en algún momento experimentaría la muerte, sino que tras comer el fruto del árbol del bien y del mal le sobrevendría inmediatamente la muerte. Teniendo en cuenta la lógica de la trama del relato, éste parece ser el significado más coherente. Ello queda de manifiesto en la respuesta de la serpiente a Eva: ella le revela

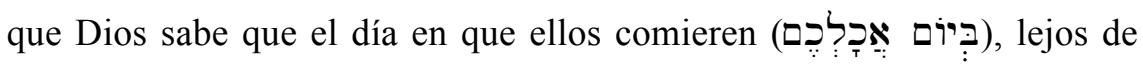

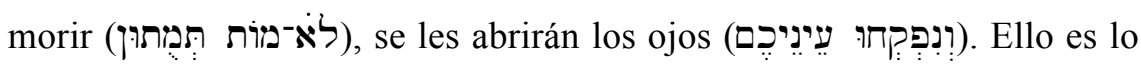
que de hecho ocurre en el relato: cuando comen del fruto, se les abren efectivamente los ojos, pero no mueren $\left(\mathrm{Gn} \mathrm{3,7).}{ }^{79}\right.$ Un pasaje semejante, si bien con una trama diversa, lo pone de manifiesto: en Re 2, 37.42.46 el rey advierte a Semei que el día en que éste saliere y cruzare el Cedrón

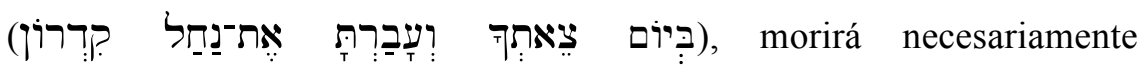
(מוֹת תתמוּת). Ello es lo que ocurre efectivamente en el día en que Semei cruza el torrente. $^{80}$

Partiendo de esta interpretación, varios exégetas señalan que la amenaza divina de muerte dada al hombre de hecho no se cumple (Gn 2,16-17). ${ }^{81}$ El problema parece haber sido percibido en la antigüedad. Así la traducción griega de Símaco intenta resolver la dificultad: no traduce

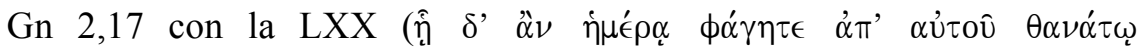
$\dot{\alpha} \pi 0 \theta \alpha \nu \in \hat{\imath} \sigma \theta \epsilon)$, sino que hace decir a la frase final que a partir de entonces el hombre comenzará a ser mortal ( $\theta \eta \nu \tau o ́ s){ }^{82}$ No parece ser otra la razón de la explicación del libro de los Jubileos en la que se interpreta que Adán murió en ese mismo día. ${ }^{83}$

79 Consecuentemente no considero sostenible la explicación de F. GIUNTOLI, Genesi, p. 108. Para el exégeta italiano, el hombre y la mujer tienen prohibido el acceso al árbol de la vida desde el momento de la desobediencia. A su juicio, ahí se ve la sanción de muerte de Dios en Gn 2,16-17. Ella habría sido eludida y disfrazada astutamente por la serpiente mediante sus palabras seductoras.

80 La interpretación propuesta por Z. ZEVIT, Garden of Eden, p. 296 n. 7 sobre

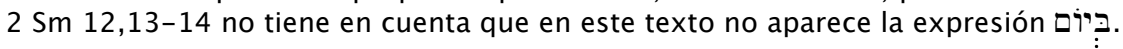

81 Cf. Z. ZeVIT, Garden of Eden, p. 124; 168; A. VAN DER KOOIJ, Paradise, p. 7.

82 Cf. A. SAlVESEN, «Symmachus in the Pentateuch» (JSSM 15), Manchester, 1991, pp. 9-10, citado en A. VAN DER KOOIJ, Paradise, p. 5.

83 Cf. J. H. ChARLESWORTH (ed.), The Old Testament Pseudoepigrapha, V. 2, Peabody, Massachusetts, 2009. En Jub 4,30 se interpreta Gn 5,5 en relación con Sal 90,4 para resolver el problema planteado. Adán muerte a los 930 años. Le faltaron 70 para cumplir los 1000 años que, según la Escritura, son como un día. De esta 
Aquí podría plantearse un problema en relación con la imagen de Dios mismo. ¿Cómo es posible que Dios amenace falsamente con un castigo que no se cumple e, implícitamente, mienta? La "lógica" del relato, de carácter mitológico, no contempla esta cuestión y plantearla supone desconocer el mundo del relato. Además de ello, el texto no duda en mostrar a un Dios "imperfecto", que "ensaya" cuando busca una compañía adecuada para el hombre, sin saber que sólo una mujer podría estar a la altura de su dignidad (cf. Gn 2,18-23). El texto pretende narrar el carácter "divino" del hombre en cuanto conocedor del bien y del mal y lo hace a través del mito de la usurpación de un árbol prohibido. Llega a alcanzar ese conocimiento pero no la inmortalidad, dado que Dios lo expulsa del jardín y pone guardias frente al árbol. El relato entiende, así, que si el hombre hubiese podido comer también del árbol de la vida, habría podido ser también inmortal. El fruto concedería lo que promete. Por otra parte, el problema del ocultamiento que Dios hace al hombre del conocimiento del bien y del mal que supone el relato, no plantea mayores problemas que el de un Dios que, por una falta histórica, castiga tan gravemente al hombre y al mundo entero. Esa sería una imagen ciertamente más terrible de Dios.

En la trama del relato, la amenaza de muerte tiene simplemente como función el mantener al hombre lejos del árbol del conocimiento del bien y del mal. ${ }^{84}$ Además, un motivo semejante es conocido en la teología mesopotámica en relación con la vida: el héroe Adapa se niega a comer del pan de vida y a beber del agua de la vida porque el dios Ea le ha susurrado que estaban envenenados. ${ }^{85}$ Ello era, en realidad, falso y Adapa habría podido alcanzar de hecho el don de la inmortalidad. ${ }^{86}$ Es decir, el dios Ea le ha mentido para impedir que él se apropie de algo considerado indebido. Algo análogo ocurre con Aqhat que rechaza el don de la inmortalidad que le ofrece la diosa Anat. ${ }^{87}$ Se puede concluir con Schüle: el obrar de YHVH no es el del Dios deuteronomista de la alianza sino

manera, Adán muere en ese día. Cf. también A. VAN DER KoOIJ, Paradise, p. 6; Z. ZEVIT, Garden of Eden, p. 124.

84 Cf. A. SCHÜLE, Prolog, p. 167.

85 Cf. ANET 102; K. JAROŠ, Die Motive der heiligen Bäume, p. 206; A. SCHÜLE, Prolog, p. 168.

86 Cf. F. GIUntoli, Genesi, p. 108.

87 Cf. A. SCHÜLE, Prolog, p. 168. 
que, en el marco del relato, sigue el plan estratégico de impedir que el hombre coma del árbol del conocimiento. ${ }^{88}$

Para el relato, el varón y la mujer han sido creados sin la capacidad de conocer el bien y el mal y sin la inmortalidad. A través de una usurpación logran apropiarse de la primera pero no de la segunda. El hombre ha llegado a ser como Dios solamente por lo que respecta al conocimiento del bien y del mal, pero no en lo que atañe a la inmortalidad. YHVH Dios ha logrado solamente privarlo de ésta última. Dios, ahora prevenido, impide que extienda su mano hacia el árbol de la vida a través de la expulsión del jardín y de la guardia de los querubines (Gn 3,22-24). Así se explica la paradoja del ser humano: es "divino" en cuanto al conocimiento pero, a pesar de ello, es mortal.

Puesto que la adquisición de la condición que tiene ha sido explicada a través de la trama de una usurpación, el autor puede vincular esa falta de la trama con otras experiencias dramáticas de vida humana que encuentra a diario. No se contiene en el pasaje, por tanto, una etiología del pecado original en cuanto tal, entendido como una causa histórica.

\subsection{La recepción posterior del relato}

Espigo aquí algunos testimonios importantes de la recepción del texto, sin pretensión de exhaustividad. En primer lugar, hay que señalar que si bien no es una lectura única, la interpretación de la muerte como consecuencia del pecado de Adán -y no como hecho natural- se deja rastrear en algunos textos tardíos. ${ }^{89}$ En Henoc 69,11 el hombre es considerado inmortal como los ángeles y Sab 2,23 enseña que fue creado en inmortalidad ( $\left(\epsilon \pi^{\prime} \dot{\alpha} \phi \theta \alpha \rho \sigma i ́ \alpha\right)$ y la imagen divina es interpretada como

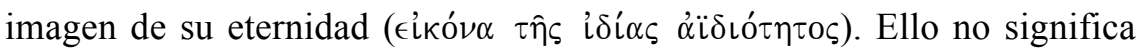
necesariamente que estos textos afirmen también la herencia inapelable de un pecado original, transmitido por generación. Si hay textos que lo sostienen (4 Esd 3,26; 7,118), ${ }^{90}$ no es una concepción generalizada:

88 Cf. A. SCHÜLE, Prolog, p. 168. Para el autor, la argumentación de H. GUNKEL, Genesis, p. 10-11 sigue siendo de referencia.

89 Cf. A. van Der KoolJ, Paradise, p. 5; F. Giuntoli, Genesi, p. 109.

90 Cf. U. WILCKENS, Der Brief an die Römer (EKK), pp. 311-312. Cf. no obstante 4 Esd 4,20-26, citado en A. PITTA, Lettera ai Romani. Nuova versione, introduzione e commento, Milano, 22001, p. 241. 
“Adán no es la causa sino solamente para sí mismo pero cada uno de nosotros se ha convertido en nuestro propio Adán" (Ap Bar 54,19). ${ }^{91}$ Tampoco en los textos de Qumrán en los cuales se habla de Adán hay una relación directa con el origen del pecado. ${ }^{92}$

En el Nuevo Testamento no nos encontramos sino con pocas alusiones al relato, especialmente en la teología paulina. Con la mentalidad de su época, ${ }^{93}$ Pablo interpreta probablemente ${ }^{94}$ a Adán como sujeto histórico y presenta la muerte como consecuencia del pecado de

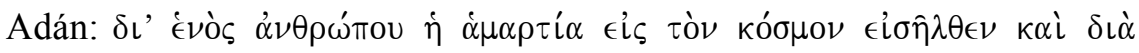

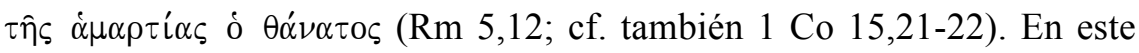
pasaje de la Carta a los Romanos, el apóstol no se atiene estrictamente a todo el texto del Génesis: no menciona a Eva o a la serpiente sino sola y exclusivamente a Adán. ${ }^{95}$ Ello se debe a que establece una sygkrisis ${ }^{96}$ con Cristo: por un hombre entró el pecado y la muerte, por un hombre

91 Texto tomado de J. Charlesworth (ed.), The Old Tetament Pseudepigrapha. Apocalyptic Literature and Testaments. V. 1, Peabody, Massachusetts, 2009, p. 640; cf. también U. WILCKENS, Römer, p. 312 n. 1028.

92 Cf. R. PENNA, Lettera ai Romani. Introduzione, versione, commento, Bologna, 2010, p. 371

93 Sobre el trasfondo judío de la figura de Adán, cf. M. GARCíA CORDERO, «La doctrina paulina sobre el «pecado original» en el entorno de la teología judía intertestamental», en CiTom 121 (1994), pp. 235-278; J. R. LEVISON, «Portraits of Adam in Early Judaism. From Sirach to 2 Baruch» (JSP SS 1), Sheffield, 1988; T.H. TOBIN, «The Jewish Context of Rm 5:12-14», en StudPhilAnn 13 (2001), pp. 159175.

94 Cf. no obstante la aseveración de J. D. G. DunN, The Theology of Paul the Apostle, Grand Rapids, Michigan - Cambridge, U.K., p. 94: "Whether Paul also thought of Adam as a historical individual and of a historical act of disobedience is less clear. Philo should remind us that the ancients were more alert to the diversity of literary genres than we usually give them credit for."

95 En este contexto, es interesante recordar la interpretación tomista: dado que la mujer no engendra sino que ofrece la materia para que el varón lo haga, si sólo hubiese pecado Eva el pecado no se habría transmitido a todos los hombres. Cf. Tomás DE AQUino, Suma de Teología I-II q. 81 art. 5; cf. I q. 92, art. 1. Para el doctor común la culpa de Eva es mucho más grave que la de Adán, a menos que se considere la condición de las personas y, en ese caso, dado que el varón es más perfecto que la mujer, su pecado es más grave. Cf. Suma de Teología, II-II q. 163, art. 4. Asimismo cf. O. H. PESCH, Katholische Dogmatik aus ökumenischer Erfahrung. Bd.1. 1/2. Die Geschichte der Menschen mit Gott, Ostfildern, 2008, p. 42.

96 Cf. R. PENNA, Romani, pp. 365-367. 
también la redención y la vida. ${ }^{97}$ Sin esta selección de solo un personaje del relato, no cerraría su razonamiento. ${ }^{98}$

En su argumentación Pablo establece una relación entre la transgresión de Adán y la muerte y el pecado (cf. Rm 5,12.19), sin detenerse a "precisar como eventualmente se transmita el pecado de Adán". ${ }^{99}$ De allí que no pueda afirmarse sin más que Pablo sea el creador de la doctrina del pecado original, transmitido por generación, si bien algunos se la atribuyen. ${ }^{100}$

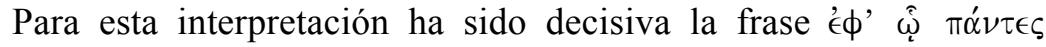

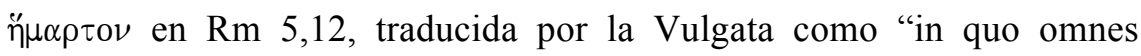
peccaverunt" y que fue retomada luego por Agustín de Hipona. El obispo africano interpreta el "in quo" como referido a Adán: todos hemos pecado en él. ${ }^{101}$ También el Concilio de Trento sigue esta traducción de la Vulgata. ${ }^{102}$ Según R. Penna los Padres griegos, en cambio, han leído aquí una afirmación, no del pecado de Adán, sino de los pecados personales de todos los hombres. ${ }^{103}$

97 En la literatura judía hay también un paralelismo contrapuesto entre Adán y Noé, segundo principio de la generación de los hombres, si bien no hay salvación para los pecadores. Cf. FILÓN, Vit Mos 2,60. Algunas otras citas pueden verse en U. WILCEKNS, Römer, p. 312 n. 1030.

98 Cf. R. PenNA, Romani, pp. 370-371.

99 Cf. R. Penna, Romani, p. 378. Cf. también J. D. G. Dunn, Theology of Paul, pp. 95-96.

100 Cf. J. A. SAYÉS, Teología, p. 379.

101 Cf. AGustín DE HiponA, De peccatorum meritis et remissione 1,10,11; J. A. FITZMYER, «The consecutive meaning of '€申' $\hat{\dot{\omega}}$ in Romans 5:12», en NTS 39 (1993), pp. 321-339, 322-323; U. WICKELNS, Römer, p. 316; A. PITTA, Lettera ai romani, p. 233; O. H. PESCH, Dogmatik, pp. 40-41. Esta exégesis ha sido dominante. Cf. L. SCHEFFCZYK, «Urstand, Fall und Erbstünde. Von der Schrift bis Augustinus» en M. Schmaus et al. (Hgg.), Handbuch der Dogmengeschichte. Bd. Il. 3. a., Freiburg i. Br. - Basel - Wien, 1982, p. 213. G. L. MüLLER, Katholische Dogmatik für Studium und Praxis der Theologie, Freiburg i. Br. Basel - Wien, 2001, p. 137 interpreta, a juicio de Pesch, de manera atenuante.

102 Cf. R. PENNA, Romani, p. 376.

103 Cf. R. PENNA, Romani, p. 376. 
Salvo la seguida por la Vulgata, la expresión 'é $\phi^{\prime} \hat{\dot{Q}}$ admite varias posibilidades de interpretación. ${ }^{104}$ Entendida en sentido causal, la argumentación paulina constata aquí que todos de hecho han pecado. ${ }^{105}$ Se trata de una universalidad del pecado que difiere claramente de la concepción judía. ${ }^{106}$ En ello puede considerarse como análoga la argumentación de Rm 1,18-3,20: tanto judíos como griegos han pecado y se hallan privados de la gracia de Dios y, por consiguiente, todos están todos igualmente necesitados de la redención en Cristo. ${ }^{107}$ Es aquí donde recae el peso de toda la argumentación paulina y el sentido último del paralelismo: existe una necesidad universal de redención y esa salvación ha entrado definitivamente con Cristo. Hay una asimetría radical entre el pecado de Adán y la gracia de Cristo ( $\mathrm{Rm} 5,12-21)$.

\section{Consideraciones finales}

Ahora bien, ¿dónde y cómo queda la doctrina sobre el "pecado original'? ¿Cómo decir una palabra sobre esta cuestión importante no sólo de la antropología sino de la soteriología? Desde hace tiempo la interpretación tradicional de la doctrina del pecado original ha sido fuertemente cuestionada y debatida. "La teología del pecado original es sin duda uno de los temas donde la tensión entre verdad e historia han suscitado los debates más encendidos". ${ }^{108}$ No es posible aquí entrar en un

104 Cf. R. PenNA, Romani, pp. 375-377. Una exposición de las interpretaciones a lo largo de la historia puede verse en J. A. FITZMYER, «The consecutive meaning of '€́' 'ì», pp. 323-328.

105 J. A. FITZMYER, «The consecutive meaning of '€́' $\hat{\omega} »$, p. 339 ha propuesto, en lugar del significado causal, una interpretación consecutiva. Siguiendo esta interpretación, se puede ver una suerte de doble causalidad, la de Adán y la de los hombres: "Thus Paul in v. 12 would be ascribing death and human sinfulness to two causes, not unrelated: to Adam and to the conduct of all human beings. The fate of sinful humanity ultimately rests on what its head, Adam, has done to it: the primary causality for its sinful and mortal condition is ascribed to him, but a secondary resultant causality is attributed to the sinful conduct of all human beings."

106 Cf. U. WICKELNS, Römer, pp. 312-313; O. H. PeSCH, Dogmatik, p. 39.

107 También A. PITTA, Lettera ai romani. p. 234 y R. PENNA, Romani, p. 368 sostienen esta relación.

108 D. BIJU-DuVAL, «La traduzione di Rm 5,12-14», en RivBiblt XXXVIII (1990), pp. $353-373,353$. 
tratamiento pormenorizado de todas las cuestiones, sino que tan solo querría ofrecer algunas consideraciones finales sintéticas, todas ellas discutibles y necesarias de discusión.

En primer lugar, hay que decir que no se puede interpretar el texto de Gn 3 como la revelación de una falta personal, histórica en los albores de la creación. Nunca hubo una transgresión personal histórica que haya engendrado la condición pecaminosa del ser humano y que, a su vez, haya traído como consecuencia la muerte de la humanidad, creada originalmente inmortal. El relato no pretende ofrecer una etiología histórica del pecado o una exposición del origen de la muerte. Todo lo dicho anteriormente permite afirmar que no es un relato sobre el "pecado original" que se transmite a la humanidad. Gn 3 no presenta una etiología del pecado sino que da una explicación del ser del hombre. El texto explica cómo éste es imagen y semejanza de Dios. Lo hace desde otra interpretación: no se lo atribuye a Dios como el primer relato sacerdotal, sino que lo relaciona con una usurpación. A pesar de esta condición de semejanza divina, el autor se confronta con una contradicción: el hombre es mortal. El autor ha dado una respuesta: ello se debe a que el hombre sólo ha podido usurpar el fruto del conocimiento del bien y del mal, pero no el de la vida. Vuelve al polvo del que ha sido tomado, por más que sea como un Dios. El "pecado original" del hombre no es más que ser precisamente hombre.

Por otra parte, una interpretación histórica del relato tendría que suponer en el hombre primitivo una madurez y una conciencia extraordinarias para poder cometer libremente una transgresión de una envergadura tal que fuese capaz de condenar a toda la humanidad. Una madurez semejante contrasta con los acercamientos de la paleoantropología y con los conocimientos sobre la evolución del ser humano: como bien dice Pesch, el límite de diferenciación entre el homínide y el homo erectus son más que difusos. ${ }^{109}$ No cabría imaginar esta conciencia madura capaz de una transgresión radical en el homo erectus, habilis o sapiens.

Además, si se afirma, siguiendo la interpretación habitual del texto, que la muerte es una consecuencia del pecado cometido en los orígenes, al menos habría que tomar al pie de la letra los otros elementos del relato

109 Cf. O. H. PESCH, Dogmatik, p. 45. 
y afirmar que también serían consecuencias la enemistad entre la serpiente y el linaje humano como así también su arrastrarse por el suelo. No habría razón suficiente para seleccionar en un mismo texto lo que debe tomarse al pie de la letra y lo que no. Por lo mismo, considerar Gn 3 como el origen histórico del pecado o de la muerte sería tan verosímil como interpretar en Gn 11,1-9 el origen histórico de la diversidad de lenguas.

A este punto, cabe hacer una precisión importante. Negar el "pecado" original no significa negar la realidad de la manifiesta inclinación al mal ínsita en el corazón del hombre (cf. Mc 7,20) y que lo hace radicalmente necesitado de perdón y de salvación. Se puede ciertamente discutir sobre la doctrina del pecado original, las diferentes formas de interpretación y sus respectivos presupuestos. No se puede discutir aquello que es el corazón de la cuestión: la absoluta necesidad de Cristo. ${ }^{110}$ Contradiciendo a Sayés: se puede cuestionar "la hondura del pecado original" - entendido como una falta histórica cometida por la humanidad en los inicios y transmitida por herencia- sin atentar contra el misterio de Cristo. ${ }^{111}$ Las Iglesias Ortodoxas -el otro pulmón con que respira el cristianismo -no dudan del carácter universal de la caída en culpa de la humanidad pero no se han apropiado nunca de la doctrina del pecado original tal como se ha formulado en el Occidente. ${ }^{112}$ Además, si no se hace un "redondeo canónico" que pase por alto la diversidad no armonizable contenida en la Escritura, entonces es posible encontrar también otras "explicaciones" del mal en el hombre y en mundo. Esta diversidad de miras hace ver lo cuestionable que puede ser elegir solo una explicación posible: tanto el relato sacerdotal $(\mathrm{Gn} \mathrm{6,12)} \mathrm{como} \mathrm{el} \mathrm{no}$ sacerdotal del diluvio (Gn 6,5) se limitan a constatar que el mal se multiplica; ${ }^{113}$ otro texto no sacerdotal parece desconocer el relato de Gn 3 $y$, lejos de afirmar que hay un pecado que se hereda con la concepción, afirma que la inclinación del corazón del hombre es mala desde su

110 Cf. O. H. PESCH, Dogmatik, pp. 38-40.

111 Cf. J. A. SAYÉS, Teología, p. 379.

112 Cf. O. H. PESCH, Dogmatik, p. 44.

113 Sobre los dos relatos, cf. A. SCHÜLE, Prolog, pp. 247-254; J.-L. SKA, Introduction to Reading the Pentateuch, Winona Lake, Indiana, 2006, pp. 60-65. 


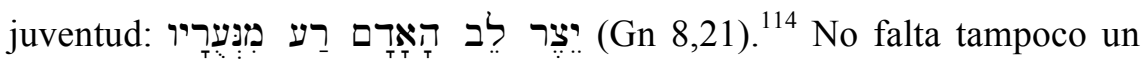
relato mitológico en el cual se insinúa que el mal está vinculado al comercio carnal entre los hijos de los dioses y las hijas de los hombres (Gn 6,1-2). Cabe asimismo notar que en los textos hay personajes agradables a Dios, como Abel, Noé y Abraham, que no parecen afectados por un "pecado original". ${ }^{115}$

Es necesario, por tanto, un abordaje nuevo de la cuestión y ello supone también encontrar un lenguaje adecuado. En este sentido, considero que más que de "pecado original" -culpa heredada por un pecado personal histórico y que se borra con el sacramento bautismohabría que hablar mejor de una condición innata, de una inclinación al mal que divide profundamente al hombre, un instinto agresivo que lo puede llevar a enfrentarse a Dios y a convertirse en lupus de su hermano. Se trata de una condición "heredada" por el hecho de ser hombres, no por una culpa cometida en los orígenes de la historia. Esta condición se actúa a lo largo de la vida humana. Ello supone la libertad del hombre que actualiza de diversos modos y grados esa potencialidad. Se trata de una condición que acompaña al hombre mientras viva. Se trata de una condición cuyo origen no es susceptible de explicación última ni puede ser respondido, como ya se ha dicho, con una interpretación literal, histórica de la trama mitológica de Gn 3. En este sentido, sería preferible

114 J.-L. SKA, «Gn 1-11: un testo sacerdotale e i suoi complementi», en E. MANICARDI / L. MAZZINGHI (a cura di), Genesi 1-11 e le sue interpretazioni canoniche: Un caso di teologia biblica. XLI Settimana Biblica Nazionale (Roma, 6-10 Settembre 2010), Bologna, 2012, pp. 49-74, 53-54 constata con varios exégetas la diversidad que contienen los textos no sacerdotales de Gn 1-11. Sobre el texto arriba indicado, cabe destacar que el relato del diluvio, como afirma el exégeta belga, no contiene ninguna relación con los relatos anteriores y en él no hay mención de la culpa de Adán y Eva o del asesinato de Abel.

115 Algunas afirmaciones de E. NARDONI, Género literario y teología, p. 83, son aquí pertinentes: "Nunca más maldeciré la tierra por causa del hombre, pues desde su infancia la inclinación (yếṣer) del corazón humano va hacia el mal. Ni volveré más a destruir a todo ser viviente como acabo de hacerlo" (Gén 8,21). Según esta afirmación, la inclinación hacia el mal, que está en el corazón humano, influye en la decisión moral desde el primer momento del uso de razón. Esto lo dice ahora de la nueva humanidad que desciende de Noé, el hombre justo y sin mancha que obtuvo el favor divino (Gén 6,8-9). Pero al referirse a la mala inclinación, Dios no hace la mínima insinuación de que ella haya sido introducida por el pecado de Adán. Parece más bien que nace con cada hombre y se transmite de generación en generación porque es parte del ser humano, cuya libertad creada tiene la tendencia a la propia afirmación con pretensiones divinas." 
no explicarlo antes que explicarlo mal o hacerlo de una manera que suscita más dificultades de las que resuelve. No hace falta mencionar aquí la extrañeza que la doctrina tradicional provoca con razón en los oídos contemporáneos.

Ello trae aparejado sin duda un problema con respecto a la imagen de Dios: ¿cómo es posible que él haya creado un ser imperfecto, falible e inclinado al mal? ¿es coherente con la constatación del relato sacerdotal que ve la creación como "buena" (Gn 1,31)? La dificultad es real y no se puede minimizar. Pero no es más ni menos compleja que el problema de la teodicea y la pregunta acerca del porqué del mal y del sufrimiento en el mundo. El problema del origen del mal en el corazón humano debe ser tratado, a mi juicio, como el capítulo antropológico del problema más amplio de la teodicea. Los límites infranqueables para responder a ésta son análogos a aquellos con que nos topamos cuando se intenta abordar la problemática de la inclinación al mal en el ser humano. Además, este abordaje desde la teodicea impide caer en la conclusión tan simplista como injustificada de que todo el mal que deforma el mundo se debe exclusivamente a la responsabilidad humana. ${ }^{116}$ Una tal teología es semejante a aquella de los sabios amigos de Job que intentan disculpar a Dios a toda costa ( $\mathrm{Jb} 34,1-37 ; 42,7-9)$. No es posible sostener que todas las ramificaciones del mal y del dolor que desarzonan al hombre y que deforman escandalosamente el mundo sean explicables a partir de una falta original, nacida de la responsabilidad humana: ¿qué pecado histórico habría podido ser tan terrible y radical como para sumir en la condena del dolor, de la muerte y del desastre extremos a la humanidad y al cosmos?

Si bien con lo que sigue el problema no se resuelve en modo alguno, es importante llamar aquí la atención sobre un hecho fundamental: la creación -y especialmente la creación del hombre- no es un hecho "cerrado" y "acabado" en sí mismo. La creación tiene desde el inicio vocación pleromatológica. Está pensada en el dinamismo de una peregrinación hacia una plenitud sin sombras que solo se puede alcanzar en la consumación definitiva. Pretender una condición humana sin esa división inherente a su condición de sujeto histórico, libre y limitado podría implicar sutilmente la pretensión, en los inicios, del hombre

116 Éste parece ser el acento puesto por T. PRÖPPER, Theologische Anthropologie, pp. 934-935, según el cual el mal es históricamente explicable a partir de la libertad del hombre. 
pleromatológico. Dada esta condición real, el ser humano necesita constitutivamente de la gracia, cuya manifestación suprema se encuentra irrevocablemente en Jesús, el Cristo muerto y resucitado.

Todo lo dicho roza, como es de esperar, la comprensión del bautismo y su efecto de "borrar la mancha del pecado original". ${ }^{117}$ Esta cancelación de la mancha del pecado original es entendida como condición sine qua non para alcanzar la salvación. De allí que, por ejemplo, el segundo Concilio de Lyon (DH 858) y el Concilio de Florencia (DH 1306) enseñan que quienes mueren tan solo con el pecado original son precipitados al infierno. Cabría revisar la clara división tradicional entre una "culpa" perdonada -una recreación a nivel ontológico-y la concupiscencia a la que el ser humano continúa expuesto durante toda su vida. ${ }^{118}$

El bautismo, estrictamente hablando, no puede borrar la herencia de una "culpa" que sólo existió en la trama de un relato mitológico y que nunca fue cometida por un sujeto histórico en los inicios de la humanidad. Por la fe y el bautismo, el discípulo creyente se injerta realmente en el acontecimiento de gracia realizado en Jesús, el Cristo y es verdaderamente "lavado, santificado y justificado" (cf. 1 Co 6,11). En este pasaje, no se trata del lavado de una naturaleza caída, considerada de manera abstracta, sino de la vida de idolatría e impureza vividas en otros tiempos: "tales fueron algunos de ustedes" (cf. 1 Co 6,9-11). En la enseñanza paulina el perdón y la justificación nunca están referidos a una naturaleza caída abstracta, sino a los pecados personales libremente cometidos, actualizando así libremente esa inclinación ínsita en el

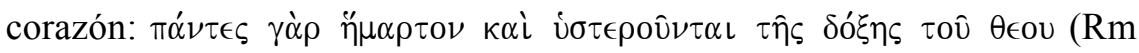

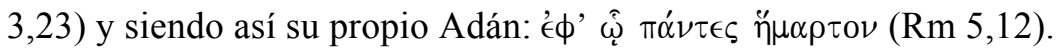

Se trata de un perdón real -no una mera sanción extrínseca- que transforma la vida del creyente por la presencia del Espíritu, pero que sin embargo deja subsistir esa íntima división con la cual tendrá que luchar durante todo su camino de seguimiento de Jesús, el Cristo. Ahora bien, la forma en que Dios nos perdona y nos ha perdonado en su Hijo puede

117 Cf. Ritual Romano, Sacramento del bautismo, n. 46.

118 La cuestión de la concupiscencia ya había ocupado a grandes teólogos desde hace tiempo. Cf. K. RAHNER, «Zum theologischen Begriff der Konkupiszenz», en: Schriften zur Theologie, Bd. I, pp. 377-414. 
entenderse de manera análoga a lo que se da entre las relaciones humanas. Así como el perdón en las relaciones humanas no crea una nueva situación ontológica estática, sino una nueva situación relacional, también en relación con Dios y en el proceso de justificación. Ello supone no entender la gracia necesariamente como una cualificación interior del alma. ${ }^{119}$ Ciertamente hay un perdón real que cambia radicalmente la vida.

En este sentido y en este contexto, sería necesario también rever la cuestión del "extrinsecismo" del simul iustus et pecator luterano. ${ }^{120}$ No faltan esfuerzos teológicos por sacarlo de la teología de controversia y contextualizarlo mejor. $^{121}$ La cuestión ha sido siempre como el documento de identidad confesional. No obstante, si bien siempre se han marcado claramente las diferencias entre los dos universos conceptuales, ${ }^{122}$ una comprensión renovada de la cuestión podría acercar la expresión de M. Lutero a lo que la Iglesia entendió -desde otros presupuestos- como la concupiscencia remanente, una vez "borrada la culpa".

Podemos decir: hay un perdón real -un perdón performativo- pero ello, sin embargo, no erradica todavía la propensión al mal y ella se actualiza no excepcionalmente en "el hombre nuevo" y, muchas veces, de manera escandalosa. Esa realidad no puede dejar intacta la interpretación tradicional. En gran medida, lo que intento expresar aquí lo dice O.

119 Cf. O. H. PESCH, Dogmatik, p. 53; id., Hinführung zu Luther, Mainz, 2004, pp. 212-226.

120 La enseñanza católica siempre ha insistido en el carácter inherente de la gracia, descartando una mera imputación extrínseca. Para una presentación sucinta de la cuestión, cf. V. M. FERnÁNDEZ, La gracia y la vida entera. Dimensiones de la amistad con Dios, Buenos Aires, 2003, p. 137. Lo arriba dicho intenta lograr una mirada no maniquea de la cuestión, en la cual las alternativas son radicales: intrínseco o extrínseco.

121 Cf. T. SÖDING, «Der Mensch im Widerspruch (Röm 7)», en F. W. HORN (Hg.), Paulus Handbuch, Tübingen, 2013, pp. 371-374, 371; id., «Die Rechtfertigung der Sünder und die Sünden der Gerechtfertigten. Anmerkungen zum Streit um »simul iutus et peccator « im Lichte paulinischer Theologie», en: T. SCHNEIDER / G. WENZ (Hg.): Gerecht und Sünder zugleich? Ökumenische Klärungen (Dialog der Kirchen 11), Freiburg - Göttingen, 2001, pp. 30-81. Cf. la crítica de este texto en S. HAGENOW, Heilige Gemeinde, sündige Christen. Zum Umgang mit postkonversionaler Sünde bei Paulus und in weiteren Texten des Urchristentums, Tübingen, 2011, p. 22.

122 Cf. O. H. PESCH, Dogmatik, p. 37 
Pesch, en pocas palabras: "El hombre no tiene sólo una inclinación al pecado, él está como hombre (aún) determinado por el pecado y evidentemente la gracia pensada como renovación interior no suprime este estado de cosas." ${ }^{23}$ Aquí cabría pensar y reflexionar acerca de la justificación y santificación no como un evento puntual, instantáneo ${ }^{124}$ sino ante todo el inicio de un proceso que culminará recién en el cara a cara (cf. Rm 5,9-10.19).

Caben, finalmente, unas breves palabras sobre el problema de la salvación de los niños que mueren sin bautismo. No entro aquí en la cuestión del bautismo de niños en sí, debatida ya desde Tertuliano. ${ }^{125}$ ¿Cómo plantear, después de todo lo dicho, esta cuestión? El magisterio de la Iglesia ha ido evolucionando en la comprensión del tema. Tradicionalmente, afirmar la absoluta necesidad de la gracia y del bautismo condujo a excluir de la salvación a los niños sin razón y sin bautismo, a crearles un limbo o un cielo morigerado o, más recientemente, a esperar su salvación. La esperanza de la salvación de aquellos que mueren sin el bautismo se fundamenta en la voluntad salvífica universal de Dios y en su misericordia. ${ }^{126}$

A mi juicio, en este planteo no siempre se tiene en cuenta que ya la mera cuestión de dudar de que los niños sin razón y sin bautismo puedan alcanzar la salvación -o sostener que el limbo "continúa siendo una opinión teológica posible" 127 - amerita una profunda discusión. En primer lugar, en ninguna parte de la Escritura se afirma que una condición heredada de pecado no actuada personalmente (como la de un niño sin uso de razón) sea suficiente para poner en riesgo la salvación o, menos aún, que determine la condenación. Cuando Agustín llega a esta conclusión no está sacando las consecuencias implícitas del dato revelado sino interpretando con sus propios lentes y desde presupuestos propios. No existe nunca un "sacar a la luz lo contenido in nuce" sin un sujeto que

123 O. H. PeSCH, Dogmatik, p. 54.

124 Así se lo ha concebido tradicionalmente. Cf. por ejemplo, TOMÁs DE AQUINo, Suma de Teología I-II 113,8. Sobre la cuestión son importantes las afirmaciones sintéticas de O. H. PESCH, Dogmatik, p. 53.

125 Cf. Tertuliano, De baptismo 18. Cf. también De anima 41.

126 Cf. COMISIÓN TEOLÓGICA INTERNACIONAL, La esperanza de salvación para los niños que mueren sin bautismo, 19 de enero de 2007.

127 Cf. ibid., n. 41. 
interviene con su forma mentis y su bagaje hermenéutico. Ello determina también las conexiones "lógicas" que establece entre los datos y condiciona las conclusiones que extrae.

Pero por otra parte, la posibilidad de condenación o, incluso también, una simple esperanza de salvación, desconoce lo que es una afirmación central del Nuevo Testamento: el mundo ha sido redimido. A. Pitta ha puesto de manifiesto que, por ejemplo, en el paralelismo de Rm 5 entre Adán y Cristo, la supremacía absoluta está en el acontecimiento salvífico. ${ }^{128}$ Es éste el corazón del mensaje del texto. Por ello, la consecuencia que se seguiría es más que grave: si en iguales condiciones -sin uso de razón- corre riesgo la salvación de un niño que muere sin bautismo, entonces se sigue que la herencia adamítica tiene de hecho más fuerza que el acontecimiento de gracia ya dado irrevocablemente en Cristo. Todo hombre nace con una herencia que lo ata y que lo atrae hacia el mal pero a la vez nace ya en una situación real de gracia alcanzada por Jesús, el Cristo muerto y resucitado. No nacemos en una situación de enemistad radical con Dios. Es posible contradecir y rechazar libremente ese acontecimiento salvífico y sustraerse de él, pero para ello es necesario el ejercicio deliberado de la libertad, caso que no es el de un niño sin razón. Si en una situación previa a la libertad personal, el "pecado original" tiene más peso, entonces la redención de Cristo no tiene ya la absoluta primacía. La situación de pecado es, así, dominante: es la ley, mientras que la redención se convierte en la excepción. Dejaría

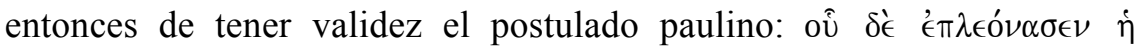
$\dot{\alpha} \mu \alpha \rho \tau \dot{\imath} \alpha, \dot{v} \pi \epsilon \rho \epsilon \pi \epsilon \rho \dot{\imath} \sigma \sigma \epsilon \cup \sigma \epsilon \nu \dot{\eta} \chi \alpha \dot{\alpha} \rho \iota \varsigma(\mathrm{Rm} 5,20)$.

Ello no supone en modo alguno afirmar que los niños que mueren sin bautismo puedan prescindir de la gracia de Jesús, el Cristo. Todo lo contrario: su salvación se fundamenta precisamente en el acontecimiento central que proclama el Nuevo Testamento. Además, entender la salvación exclusivamente en relación al pecado es una interpretación más que reductiva y unilateral. Todo hombre necesita ser salvado, pero no solo del pecado sino también del dolor, del sufrimiento y de la muerte. La salvación ofrecida por el Cristo muerto y resucitado abraza toda la condición doliente del ser humano. No por nada, el último libro del canon neotestamentario habla de la salvación como imágenes que enternecen:

128 Cf. A. PITTA, Lettera ai romani, pp. 237-239. 
Dios no solo perdonará los pecados, sino que fundamentalmente enjugará toda lágrima de los ojos. No habrá más muerte, ni fatiga, ni gritos, ni llanto (cf. Ap 21,4). El retorno al polvo no será la última palabra.

ADRIÁN TARANZANO ataranzano@hotmail.com 